\title{
Effect of reservoirs on streamflow and river regimes in a heavily regulated river basin of Northeast Spain
}

Vicente-Serrano, S.M. ${ }^{1 * *}$, Zabalza-Martínez, J. ${ }^{1}$, Borràs, G. ${ }^{2}$, López-Moreno, J.I. ${ }^{1}$, Pla, E. ${ }^{3}$, Pascual, D. ${ }^{3}$, Savé, R. , Biel, C. ${ }^{4}$, Funes, I. ${ }^{4}$, Martín-Hernández, N. ${ }^{1}$, Peña-Gallardo, M. ${ }^{1}$, Beguería, S. ${ }^{5}$, TomasBurguera, M. $^{5}$

${ }^{1}$ Instituto Pirenaico de Ecología, Consejo Superior de Investigaciones Científicas (IPE-CSIC), Zaragoza, Spain; ${ }^{2}$ Oficina Catalana del Canvi Climàtic, Generalitat de Catalunya, Barcelona, Spain; ${ }^{3}$ Centre de Recerca Ecològica i Aplicacions Forestals (CREAF), Bellaterra, Barcelona, Spain; ${ }^{4}$ IRTA, Environmental Horticulture, Torre Marimon, Caldes de Montbui, Barcelona, Spain; ${ }^{5}$ Estación Experimental de Aula Dei (EEAD-CSIC), Zaragoza, Spain

*Corresponding autor: svicen@ipe.csic.es, Tel: +34976369393

\section{Abstract}

Dams modify downstream hydrology because they alter natural river regimes and divert river flows. The Segre Basin is one of the main tributaries of the Ebro River in Northeastern Spain, and has a drainage area of 13,000 $\mathrm{km}^{2}$. In this study, we used data on long-term (1951-2013) river flows and climatic series to analyze the downstream cumulative effect of dams on natural river regimes and the disassociation between changes in climate and runoff in the Segre Basin. The headwaters of this basin are in the Pyrenees Mountains, and water flow has been highly regulated since the second half of the twentieth century due to the construction of numerous dams. We compared long-term monthly averages of upstream and downstream sectors, and assessed the relationship between the climatic and hydrological time series. Our results show that the progressive increase of the impounded ratio index (reservoir capacity) increased the disassociation between climate and runoff. This markedly exacerbated the negative trend in downstream runoff, so this decline that cannot be solely explained by climatic changes. Our results provide evidence that reservoirs can cause a significant decline in downstream runoff and significant alterations of natural river regimes. 
29 Key words: River regime, runoff trends, dams, water use.

\section{Introduction}

Water is an essential resource for agriculture, urban residents, and the natural environment of the Mediterranean region (García-Ruiz et al., 2011). This region has strong inter-annual climatic variability (Lionello, 2012), with a summer dry period in which there is great water demand (Iglesias and Mínguez, 1997; García-Ruiz et al., 2011). The mismatch between water availability and demand has led to the creation of many dams, which store water during rainy periods and supply irrigated fields and urban areas during the dry season (Döll et al., 2009; Aus der Beeck et al., 2010). Water from these dams is also used for hydropower (López-Moreno et al., 2008).

Dams have significant effects on downstream hydrology because they alter natural river regimes and divert river flows for different uses (López-Moreno et al., 2004). Thus, the ability to store water in reservoirs has strongly increased water demands in recent decades because it has led to significant increases in irrigated areas (Batalla et al., 2004; Kilic et al., 2006). In Spain, there has been a general decrease in streamflow in the last five decades, and this decrease has been more intense in the most regulated river basins (Lorenzo-Lacruz et al., 2012) because they provide water to different economic sectors. Dam regulation and water transfers between basins have also decreased streamflows and exacerbated droughts in downstream regions (López-Moreno et al., 2009; Lorenzo-Lacruz et al., 2010 and 2013).

In parallel, increasing water regulation and demand in Spain during recent decades (Duarte et al., 2014) has occurred together intense climatic and hydrologic changes. These changes include a general reduction of precipitation (González-Hidalgo et al., 2011), more frequent and severe droughts (Hoerling et al., 2012; Vicente-Serrano et al., 2014), and strong increases of atmospheric water demand (VicenteSerrano et al., 2014b) due to higher temperatures (Brunet et al., 2008) and decreased relative humidity

(Vicente-Serrano et al., 2014c and d). This changes have been especially acute in the Northeast Iberian 
Peninsula, which suffered from significant droughts in the last decade (López-Bustins et al., 2013) and experienced a general shortage of water resources (Martín-Ortega et al., 2012; March et al., 2013).

The Segre River Basin, with a drainage area of $13,000 \mathrm{~km}^{2}$, is located between the regions of Aragon and Catalonia, in the Northeast Iberian Peninsula. This region is characterized by strong climatic and hydrological diversity (Sacasas, 2007), and has been greatly affected by floods and droughts in recent centuries (Barriendos et al., 2003; Thorndycraft et al., 2006). Studies of the headwaters of the Segre Basin have documented a general decline of water resources over the last five decades. Buendía et al. (2015) showed that the Noguera Pallaresa River (the main tributary of the Segre River) has undergone a notable reduction in streamflow during late spring and summer. In addition, natural vegetation in this region has dramatically expanded because of the abandonment of traditional agricultural activities and the marginal productivity of the slopes (García-Ruiz and Lana-Renault, 2011). Afforestation is also linked to the declining runoff in the headwaters of the Segre Basin (Buendía et al., 2015 and 2015b), as in other basins of the Spanish Pyrenees (Beguería et al., 2003; Gallart and Llorens, 2003).

Although changes in climate and land cover may explain many of the changes in streamflow during recent decades, the increased river regulation by dams in the last century has also had a major impact on the Segre River Basin. Irrigated agriculture has significant economic importance in this region (Pascual et al., 2006; Matas, 2015), but the consequences of increased irrigation and water regulation on streamflow are unknown. Given the complex interactions of climate change, land cover changes, and water management, it is difficult to determine the role of agricultural water demand on changes in streamflow in the Segre River.

In this study, we used long-term data (1951-2013) on river flows and climatic series to analyze the cumulative downstream effects of dams and agricultural water demands on natural river regimes and on the disassociation of climate from runoff in the Segre Basin. The objective is to analyze changes in the availability of water resources throughout the Segre Basin and to identify interactions between changes in climate and streamflow due to dams and changing water demands. 


\section{Study area}

The drainage basin covers 13,000 $\mathrm{km}^{2}$, and includes the Segre River (8167 $\mathrm{km}^{2}$; the main tributary

81 of the Ebro River), the Noguera Pallaresa River (2807 km²) and the Noguera Ribagorzana River (2061

$82 \mathrm{~km}^{2}$ ) (Figure 1). The elevation ranges from $175 \mathrm{~m}$ to more than 3,200 $\mathrm{m}$ in the Pyrenees. The average 83 precipitation is approximately $814 \mathrm{~mm} \mathrm{year}^{-1}$, although there are large differences between the Pyrenean 84 headwaters $\left(>1,100 \mathrm{~mm} \mathrm{year}^{-1}\right)$ and the southern lowlands $\left(<400 \mathrm{~mm} \mathrm{year}^{-1}\right)$. Annual reference 85 evapotranspiration in the headwaters is less than $600 \mathrm{~mm}$ year $^{-1}$, but exceeds $1,100 \mathrm{~mm}$ in the south, near the mouth of the Ebro River (Vicente-Serrano et al., 2007). Under a natural regime, the river has a notable seasonality, with the main flow during May and June due to snowmelt and high precipitation during spring. Nevertheless, significant precipitation from storms can occur during the summer months (de Luis et al., 2011).

The population of the basin has increased 60\% from 1900 to 2010. Total population in 2010 was 422,000 inhabitants Agroindustry on irrigated lands and intensive livestock management are the main economic sectors. The basin has 144,000 ha with irrigation, based on the canals of Urgell, Pinyana, Aragón y Catalunya, and Segarra-Garrigues. Currently there are 35 reservoirs in the Segre Basin, an increase from 15 in 1951 (Figure 2) and the total storage capacity is $2084 \mathrm{hm}^{3}$. Despite the large number of dams, seven reservoirs account for $94 \%$ of the total water storage capacity. Most water regulation is in the headwaters and middle reaches of the Noguera Ribagorzana River and the Noguera Pallaresa River, with the reservoirs of Escales $\left(163 \mathrm{hm}^{3}\right)$, Canelles $\left(687.5 \mathrm{hm}^{3}\right)$, Santa Anna (236.6 $\left.\mathrm{hm}^{3}\right)$, Talarn (205.1 $\left.\mathrm{hm}^{3}\right)$, and Camarasa $\left(163 \mathrm{hm}^{3}\right)$. The Segre River is regulated by the Oliana Reservoir $\left(101 \mathrm{hm}^{3}\right)$ and the Rialb Reservoir $\left(402.8 \mathrm{hm}^{3}\right.$ ), established in 2000. The ratio between water storage and capacity has not changed over time.

\section{3. Materials and methods}




\subsection{Hydrologic data}

The Ebro river Basin Management Authority (Confederación Hidrográfica del Ebro) provided all data on monthly streamflow in the Segre Basin. After checking all available gauging stations, we used monthly streamflow data from 8 stations. The selected stations had less than 15\% data loss from 1951 to 2013. Gap filling was performed by linear regression analysis. The independent series in the regression models was in the same river or a close tributary of the river series with missing data and affected by similar regulation conditions (e.g., the gauging stations located in the headwaters were filled using available data in the headwaters). The gauging stations located in the lower area of the basin showed very few data gaps ( $<1.1 \%$ in all the cases). The minimum Pearson's correlation coefficient between the series in the model was set at $\mathrm{R}=0.6$. Figure 1 shows the locations of the selected stations. Four stations are upstream of the main reservoirs (Puigcerdà, Organyà, La Pobla de Segur, Pont de Suert) and four are downstream of the reservoirs (Oliana, Pinyana, Balaguer, Seròs). We also used data on monthly total reservoir storage, inflows to the reservoirs, and releases downstream of the dams in each of the seven reservoirs from the beginning of their operation dates. The average monthly water extractions for urban and irrigation uses in the basin were also available, as well the monthly flows into the main irrigation canal of the basin, the Canal d' Urgell.

\subsection{Climate data}

Monthly total precipitation, monthly average maximum temperature (Tmax), and monthly average minimum temperature (Tmin) were obtained from the MOPREDAS and MOTEDAS datasets (GonzálezHidalgo et al., 2011 and 2015). The datasets were updated to 2013 using the raw time series of precipitation and temperature from the Spanish Meteorological Agency (AEMET). These are dense, quality-controlled, and homogenized datasets of monthly climatic variables and are some of the best available climate datasets for Spain. We used a subset of 243 precipitation and 164 temperature stations that cover the entire Segre Basin and its surroundings. Meteorological data is unevenly distributed and 
does not cover the entire Segre Basin, so the local data measured in the meteorological stations was put into a regular $500 \times 500 \mathrm{~m}$ grid using a regression-based interpolation (Ninyerola et al., 2000). The independent variables of elevation (obtained from a 100 m grid, see below), latitude, longitude, and distance to the Mediterranean Sea were used to predict monthly precipitation, Tmax, and Tmin. To interpolate precipitation, we also used the mean elevation within a radius of 5 and $10 \mathrm{~km}$ to consider the greater influence of relief on precipitation. MiraMon software was used to obtain the gridded climatic layers (Pons, 2007).

Correlation between variables (collinearity) can complicate the interpretation of results. To prevent this problem, a forward stepwise procedure, with 'probability to enter' set to 0.01 , was used to select only significant variables, as recommended by Hair et al. (1998). The results of this method are inexact because the predicted value of a climatic variable does not coincide with the actual data collected at weather stations. Thus, residuals were interpolated using inverse distance-weighting and subtracted from the simulated grids. A total of 768 monthly gridded layers for monthly precipitation, Tmax, and Tmin were obtained (12 months x 64 years). The grid layers were validated by a jackknife resampling procedure (Phillips et al., 1992). We calculated the mean absolute error (MAE) of each gridded data layer. For precipitation, the average MAE for the different monthly layers is $11.04 \mathrm{~mm}$, which can be considered highly accurate. For Tmax, the average MAE is $0.94^{\circ} \mathrm{C}$. For Tmin, the average MAE is $1.0^{\circ} \mathrm{C}$. Agreement Index D (Willmott, 1981), which is a relative and bounded measure of model validity. It scales with the magnitude of the variables, retains mean information and does not amplify outliers. A D value of 1 corresponds to a perfect match of estimations to the observed data. This statistic provides very good results for the different layers (averages of $0.95,0.96$ and 0.96 for precipitation, Tmax and Tmin, respectively). There are not important differences between the different monthly layers, showing the time series of the monthly D and the MAE very few differences between 1951 and 2013 (Figure 3). Moreover, D values do not show noticeable differences as a function of the climate seasonality in the region. 
Using Tmax- and Tmin-gridded layers, we calculated the atmospheric evaporative demand (AED)

using the equation of Hargreaves and Samani (1985), which only requires information on temperature and extraterrestrial solar radiation:

ETo $=0.0023 \times \mathrm{Ra} \times \mathrm{R}^{0.5} \times(\mathrm{T}+17.8)$

where ETo is reference evapotranspiration, $\mathrm{R}$ is the difference between Tmax and $\operatorname{Tmin}\left({ }^{\circ} \mathrm{C}\right), \mathrm{T}$ is the mean monthly temperature $\left({ }^{\circ} \mathrm{C}\right)$, and $\mathrm{Ra}$ is the extraterrestrial solar radiation in equivalent evaporation $\left(\mathrm{mm}\right.$ day $\left.^{-1}\right)$, which depends on latitude and day of year. This method provides reliable estimates of ETo when meteorological data are unavailable for estimation of the radiative and aerodynamic components of the atmosphere (Vicente-Serrano et al., 2014a; Vicente-Serrano et al., 2014b).

We obtained the drainage basin corresponding to each gauging station using a digital elevation model (DEM) at a resolution of $100 \mathrm{~m}$ and the Basin tool in ArcGIS 10.2. This allowed comparison of the average climatic series (precipitation and ETo) of the drainage area at each gauging station with the monthly streamflow data. The sub-basins located in the same stream include all sub-basins upstream and not only the part of the basin between upstream and downstream station.

\subsection{Statistical analysis}

We calculated the influence of the 7 reservoirs of the river regimes by determining the average monthly inflow, storage, and release downstream into the dams. The reservoirs of Canelles and Santa Anna are connected, so were considered as a single reservoir in this analysis. Trends in monthly reservoir inflow, storage, and release downstream into the dams were determined by the nonparametric MannKendall tau coefficient. This is more robust than parametric coefficients and does not assume normality of the data series (Lanzante 1996). Statistically significant differences were defined as those with $p$-values less than 0.05. To determine the magnitude of changes, a regression between time (independent variable) and the hydrological series (dependent variable) was used. The slope (m) of each model indicates the 
magnitude of change. Changes in climatic variables and streamflow were assessed using the same approach.

To determine changes in the dependence of streamflow on climate variability, we calculated the annual runoff coefficients (ratio of streamflow to precipitation, using hydrological years, from October to September). The time-scale at which streamflow responds to cumulative climatic conditions depends on geography and season (López-Moreno et al., 2013). Nevertheless, we found that total annual streamflow (October-September) in the different stations is mainly driven by precipitation during the same period. This allows determination of possible changes in the relationship between precipitation and streamflow during the analyzed period. This analysis was also repeated at a monthly scale; in this case we recorded the period of $n$ months in which the cumulative precipitation better explained streamflow variability, as described by López-Moreno et al. (2013). The significance and magnitude of changes in the annual and monthly ratios of precipitation and streamflow were also calculated. To determine the possible influence of ETo on change in the runoff coefficients, we detrended the series of coefficients and correlated them with de-trended ETo series in each basin. The series were detrended using linear regression and residual values, being the runoff coefficients and the ETo the dependent variable and the series of years the independent variable. We used de-trended series to avoid erroneously increase the correlation coefficients.

Finally, following Beguería et al. (2003) and López-Moreno et al. (2011), we created monthly statistical linear models based on regression analysis. The use of linear relationships between regional climatic variable and streamflow offered a very simple framework with the possibility of interpreting the residuals of the model as the unknown element in the balance approach and the possibility of studying the changing relationship between the variables through time. We performed a stepwise multiple linear regression model between the climatic (precipitation and ETo) (independent variables) and streamflow (dependent variable) in each sub-basin, with the form:

$$
S_{i}=m+a P_{i, n}+b E T o_{i, n}
$$


Where $S$ is the observed streamflow in the month $i, m$ is the constant of the multivariate regression

201 model, $a$ and $b$ are the coefficients, $P$ is the precipitation in the month $i$ accumulated over a period of $n$ 202 months, ETo is the reference evapotranspiration. The models provide streamflow predictions only based 203 on the observed evolution of the climate variables used.

Streamflow was predicted from precipitation and ETo series, using periods of accumulation of these variables. We used the period that showed the highest correlation with the monthly streamflow. This approach takes into account that the period from the arrival of water inputs in the form of precipitation

207 (and also the water outputs in the form of evapotranspiration) to a given water usable source (streamflow) may strongly differ as a function of the basin characteristics, climate conditions and river regimes (LópezMoreno et al., 2013). The percent change in predicted streamflow, based on climate changes between 1951 and 2013, was compared with observed streamflow change. Significant differences between the magnitude of observed and predicted change of streamflow were assessed by comparing the slopes of a 212 linear model, with time as the independent variable. For this purpose, a statistical test for the equality of regression coefficients was used (Paternoster et al., 1998).

\section{Results}

\subsection{Alteration of streamflow regimes by reservoirs}

The seven large reservoirs analyzed in this study were managed similarly (Figure 4). These reservoirs reached maximum water storage in May-July to satisfy the water demands for summer 219 irrigation. Thus, river inflows are greater than water releases from late winter to early summer. In the water releases are greater than inflows from July to September to satisfy the demands of the irrigation

222 polygons. Several reservoirs (Escales, Talarn, Camarasa, and Oliana) reduce water storage during winter months, generally to increase hydropower production during this period of high electricity demand. 
The alteration of the river regimes by dams has also led to differences in monthly changes of

225 inflows and releases. Figure 5 shows the magnitude of changes in monthly water inflow, release, and storage. In general, inflow and release had negative trends during most months, but the decrease was difference between inflows and outflows during the summer irrigation campaigns.

\subsection{Changes in climate}

Figure 6 shows the changes of seasonal and annual precipitation and ETo in the drainage basin of the gauging station of Seròs (1951-2013). This gauging station has the lowest elevation, so it can be considered to summarize the behavior of most of the Segre Basin. The Segre Basin shows a strong decrease of summer precipitation during the study period. It averaged about 3,000 $\mathrm{hm}^{3}$ per year in the 1950s and about $1,800 \mathrm{hm}^{3}$ per year in the last decade (44.7\% reduction over 63 years). Increased precipitation in winter (which was not statistically significant) did not compensate for this strong reduction of summer precipitation. The strong decrease in summer precipitation explains the strong reduction of annual precipitation in the whole basin, from 10,200 $\mathrm{hm}^{3}$ per year in the 1950 s to $8,700 \mathrm{hm}^{3}$ per year in the last decade (16.2\% reduction over 63 years).

ETo increased significantly over time, especially during the summer months $(8.5 \%$ increase over 53 years). The ETo changes were moderate in other seasons, being statistically significant only in spring. As with precipitation, the long-term change of ETo was mainly driven by changes during the summer, which increased by $6.4 \%$ over 63 years $\left(12,400 \mathrm{hm}^{3}\right.$ year $^{-1}$ to $\left.13,100 \mathrm{hm}^{3} \mathrm{year}^{-1}\right)$.

The changes in the whole basin were mostly observed at the different gauging stations of the different sub-basins, from the headwaters to the middle and lower courses of the rivers. The precipitation 
decrease and ETo increase were statistically significant from June to August in all drainage basins (Table

250 1). The magnitude of the changes were similar for gauging stations of the headwaters (blue), which were unaffected by changes in water regulation, and gauging stations downstream of the dams (orange). This is because of the great importance of precipitation in the headwaters and the low spatial variability of ETo changes in the basin.

\subsection{Changes in streamflow}

Given the observed changes in climate, we expected a general reduction in streamflow in the headwaters and the lower reaches of the basin. Nevertheless, the magnitude of this change was very different in these two regions. Figure 7 shows examples of changes in seasonal and annual stream flows in the headwaters (Organyà) and lower reaches (Seròs). At Organyà there was a general decrease of stream flow in all seasons, but this was only significant during summer (40.6\% reduction over 63 years), matching the observed changes in climate. Annual streamflow declined by $27.6 \%$ at Organyà. In contrast, Seròs had statistically significant declines during all 4 seasons. Although the main decrease was during summer (66.9\%), there were also differences in the other 3 seasons (57.3\%, 59.6\%, and 62.6\%). This explains the strong reduction in annual streamflow (61.8\%), from about $3600 \mathrm{hm}^{3}$ year ${ }^{-1}$ in the 1950 s to about $1600 \mathrm{hm}^{3}$ year ${ }^{-1}$ in the last decade.

Therefore, our results indicate that declines in streamflow were much more important in the medium and lower reaches of the rivers, after the main dams of the Segre Basin. This is further illustrated in Figure 8, which shows monthly streamflow changes in different gauging stations in the headwaters (black) and lower reaches (red) of the Noguera Ribagorzana River and the Noguera Pallaresa River (left) and Segre River (right). In the headwaters of the Noguera Ribagorzana River and the Noguera Pallaresa River, there are significant decreases of streamflow during summer (May to September in Pont de Suert and July to September in La Pobla de Segur). Nevertheless, in Pinyana (located after the dams at Canelles and Santa Anna) there was a significant decrease during all months except August. In the Segre River, the 
magnitude of streamflow decrease in the lower reaches (Balaguer and Seròs) was much larger than that in the headwaters (Organyà and Puigcerdà). This pattern also occurred in the other gauging stations (Table 2). Thus, the entire Segre Basin has been affected by a strong reduction in streamflow, with especially dramatic changes in the lower reaches of the rivers.

\subsection{Changes in the relationship between climate and streamflow}

Figure 9 shows the evolution of the annual runoff coefficient at the 8 gauging stations. For stations in the headwaters (Pont de Suert, la Pobla de Segur, Puigcerdà, and Organyà), there were no statistically significant changes in this ratio, but there was a $12.2 \%$ reduction of the runoff coefficient at the Puigcerdà station. This means that the decreased streamflow observed in the headwaters coincided with reduced annual precipitation. On the contrary, at gauging stations downstream of the main dams (Pinyana, Oliana, Balaguer, and Seròs), these coefficients showed strong decreases. In Oliana (the first gauging station that is downstream a large reservoir in the Segre River), there was a reduction of $14.4 \%$. In the lower courses of the rivers (after the main dams and the irrigated areas) the coefficients show strong and statistically significant decreases, with reductions greater than 50\% from 1951 to 2013.

Analysis at the monthly scale indicated similar trends. Table 3 shows the magnitude of changes in the ratio of monthly streamflow to precipitation in the eight sub-basins. In this analysis, the optimum accumulation period of precipitation was assessed for each month and station (considering periods from 1 to 12 month cumulative precipitation prior to the analyzed month), selecting those showing a higher correlation coefficient. The optimum accumulation period of precipitation is showed for each month and gauging station. In general, the runoff ratios decreased during most months at most stations upstream of the main dams. At Puigcerdà and Organyà, there were negative trends in all months except May, August and September. At the two gauging stations in the headwaters of the Noguera Pallaresa River and the Noguera Ribagorzana River (La Pobla de Segur and Pont de Suert), the monthly ratios also decreased during most months. With the exception of Puigcerdà in August, these decreases were mainly during in 
the summer months and from October to January. These reductions were much larger at gauging stations 300 downstream of the main dams. At these downstream stations, the monthly ratios between precipitation and streamflow showed statistically significant reductions most months of the year, in some cases more than $80 \%$. In addition, there were few seasonal differences in the magnitude of the observed changes.

We also examined whether the observed increase of atmospheric evaporative demand could lead to greater evapotranspiration when water is available, thereby explaining the temporal variability in the runoff coefficient. The correlations between the annual runoff coefficient of the detrended series of precipitation and streamflow with annual ETo were mostly negative at the different sub-basins; this means that a greater ETo contributed to lower annual streamflow in relation to precipitation. Nevertheless, these correlations were not strong, and the correlation was only statistically significant at the Balaguer basin $(\mathrm{R}=-0.33, \mathrm{p}<0.01)$. In the stations of Seròs and Balaguer (in the lower reaches of the Segre river), we found that years of low runoff coefficient coincided with greater ETo values. This relationship is more evident since the early 1980s (Figure 10), a period when ETo increased more notably. At the monthly scale, the correlation between the runoff coefficient and the detrended ETo had notable seasonal and spatial differences (Table 4). There were mostly negative correlations at the different stations, but no general pattern distinguished stations that were upstream and downstream of the main reservoirs. Nevertheless, with the exception of Pinyana and Oliana, in which the correlations were positive, the different stations had negative and significant correlations during the summer months. This suggests that increased ETo may have contributed to the reduced streamflow during these months, mainly in stations downstream the main reservoirs.

We created monthly streamflow models to explain streamflow variability and changes in each monthly series at the eight gauging stations. Figure 11 shows an example of the observed and predicted July streamflow at the Seròs station. According to climate, the predicted streamflow decreased by $47.4 \%$, but the observed decrease was $68.7 \%$. This means that observed streamflow evolution shows a decrease of 21.3 percentage points higher than that expected by climate evolution. The predicted streamflow based 
on climatic changes explains more than $45 \%$ of the variance in observed streamflow during most months at most stations, in regulated and non-regulated basins (Table 5). Nevertheless, a comparison of changes in regulated and non-regulated basins shows several differences. In stations at the headwaters, although observed and predicted streamflow mostly decreased, there were no major differences in the magnitude of changes between observed and predicted streamflows. This suggests that the observed changes in climate explain most of the changes in streamflow (Figure 12). On the contrary, at stations located downstream of the main reservoirs, the observed changes were greater than predicted by climate data, with the exception of the station at Oliana. These differences were statistically significant mainly during the spring and summer months. These results suggest that factors other than climate affected changes in streamflow in the lower areas of the basins during the spring and summer months.

The patterns we observed in the lower areas of the rivers are probably related to the increased irrigation demands in the basin. Thus, the average monthly water extraction from the different rivers had a clear seasonal pattern that resembled the divergence between observed and predicted streamflow. On average, water extraction in the entire basin was lower from October to March, but greater from May to July (Figure 13). The average magnitude of water extraction during summer months is much greater than the maximum summer streamflow observed at the Seròs station between 1951 and 2013. Therefore, the high water demands during summer months can only be satisfied when water is stored in the reservoirs from late winter to early summer. On the other hand, there are no complete series on the changes in water extractions from the basin. Nevertheless, the available series of water diverted during the summer into the main irrigation canal of the basin (Canal d'Urgell) clearly increased since the beginning of the 1960s. Although there are missing data for the period of 1992 to 2002, available information during the last decade shows that canal flows have increased from about $140 \mathrm{hm}^{3}$ in the 1960 s to about $250 \mathrm{hm}^{3}$ in the last ten years. This indicates that the canal flows were greater than streamflow in the Segre River at the Seròs station, mainly during the strong drought that affected the basin between 2006 and 2008. 


\section{Discussion and Conclusions}

We analyzed changes in streamflow and climate in the Segre Basin of Northeastern Spain between 1951 and 2013. Water in this basin is highly regulated, given the existence of seven large reservoirs. These reservoirs have changed the river regimes downstream to compensate for the mismatch between water availability (mainly from precipitation and snowmelt during winter and spring months) and water demand (mainly during summer months). This pattern is similar to most of the regulated river basins in Spain, in which reservoirs supply water for agriculture (López-Moreno et al., 2004). In the entire Ebro Basin, Batalla et al. (2004) identified large modifications of the river regimes, and identified an inversion of the seasonal pattern due to water releases for irrigation during summer. This also occurs in the main reservoirs of the Segre Basin, and has greatly affected the river regimes. Reservoirs have maintained summer streamflow downstream of the main dams, a pattern that also appears in most river basins of Spain. Lorenzo-Lacruz et al. (2012) showed that regulated and non-regulated river basins had very different magnitudes of streamflow changes in the Iberian Peninsula since 1950. In particular, they showed that while non-regulated basins had decreased streamflow during summer months, highly regulated basins had increasing streamflow during summer months.

We found no positive changes in summer streamflow over time in the Segre Basin. Nevertheless, we also found that despite the increasing aridity, the storage levels of the main reservoirs have not notably decreased even though streamflow has declined. Dam management seeks to ensure an adequate water 367 supply during summer. López-Moreno et al. (2004) showed a similar pattern in the western Spanish Pyrenees, in that reservoir management adjusted to changes in streamflow and hydrological regimes. These changes in the Segre Basin also include adjustment for earlier spring peaks of flow due to the earlier snowmelt, as reported by Morán-Tejeda et al. (2014) for most natural basins in Spain.

In the Segre Basin, and independently of the documented changes in the seasonality of river regimes, the main consequence of increasing river impoundment according to our results is a greater reduction of streamflow at the lower reaches of rivers relative to the headwaters. In the headwaters of the 
Segre Basin, the annual streamflow reduction from 1951 to 2013 ranged from $16.7 \%$ at the La Pobla de Segur station to $32.8 \%$ at the Puigcerdà station. Moreover, the reduced streamflow in the headwaters is more important during the summer months. In contrasts, in the lower reaches of the Segre Basin, the reductions ranged from $61.8 \%$ at the Seròs station to $91.3 \%$ at the Balaguer station during the same period, and there were no notable seasonal differences.

The spatial variability of climate changes in the basin cannot explain the different changes in streamflow at the headwaters and the lower reaches. Thus, runoff in the basin is mainly recorded in the Pyrenean headwaters (López-Moreno et al., 2011; Buendía et al., 2014), a common pattern in Mediterranean regions (Viviroli and Weingartner, 2004; Viviroli et al., 2007). There was a strong decrease of precipitation in the headwaters of the Segre Basin, and this was more pronounced than in other areas of the Pyrenees (López-Moreno et al., 2011) and the Iberian Peninsula in general (GonzálezHidalgo et al., 2011). The dramatic reduction of summer precipitation from 1951 to 2013 (44.7\%) was responsible for significant droughts at the end of the 2000s (López-Bustins et al., 2013). Although we estimated changes in atmospheric evaporative demand based on temperature data (because time series of other meteorological variables necessary for an estimation of the aerodynamic and radiative components were unavailable), the increase of reference evapotranspiration was similar to that reported by other recent studies in the Iberian Peninsula (Vicente-Serrano et al., 2014b; Azorín-Molina et al., 2015), which considered more variables for more accurate quantification. As with precipitation, the main changes in ETo were during summer, with an increase of 8.5\% from 1951 to 2013. This indicates that increased climate stress, mainly during summer months, has affected the Segre Basin. The seasonal streamflow changes in the headwaters seem to be related to climate changes, but the changes in the lower reaches are also due to increased water use for agriculture and for the local residents.

The seasonal patterns and the magnitude of changes in streamflow at gauging stations in the lower reaches of the basin differ from those observed from water releases in the main reservoirs. The later have tended to ameliorate the large reduction of summer releases relative to summer inflows. On the contrary, 
at gauging stations in the lower reaches, there was no clear seasonality in streamflow reduction. The 400 different seasonal patterns observed for reservoir releases (river and canal flows) and streamflows 401 recorded at gauging stations in the lower reaches may be explained by two factors: (i) water storage during winter and spring months and (ii) flow diversion from the dams to the canals and significant water consumption by irrigated lands during summer. As an example of this pattern, the Canal d'Urgell has not 404 changed the water concession by the Ebro Basin management authority in the last six decades $\left(33 \mathrm{~m}^{3} \mathrm{~s}^{-1}\right.$, 405 corresponding to a total of $262 \mathrm{hm}^{3}$ during summer months), but summer canal flow since the beginning of the 1960s has increased and reached the maximum of the concession each year during the last decade. Some of the water is returned to the Segre River after crossing the irrigation districts, explaining why the streamflow decrease at Balaguer (upstream of the water returns) is greater than at Seròs (downstream of the water returns). Nevertheless, water returns have declined in recent decades, even though irrigated 410 lands have not noticeably increased (only 5,000 ha are currently irrigated by the Canal Segarra411 Garrigues), because of the trend toward more intensive irrigation (Pinilla, 2006; Clop et al., 2009). In addition, the increased atmospheric evaporative demand has probably increased water consumption in cultivated regions, as observed in other regions of Northeastern Spain (García-Garizabal et al., 2014), thereby reducing water returns to the river. Thus, we found that temporal variability of the ETo in the basin has a clear influence on the annual imbalance between precipitation and streamflow, and this pattern is most prominent in the lower reaches of the rivers during summer months, when there is greater water consumption by crops.

Therefore, dam operations and the use of water for irrigation explain most of the observed changes in the lower reaches of the Segre Basin, and climate has had a decreasing influence on streamflow during the study period. Based on changes in climate alone, we showed that streamflow should have decreased less than $40 \%$ in the lower areas of the basin, but the actual decrease averaged more than $60 \%$.

Estimation of the percentage of streamflow reduction due to climate change is difficult because climate interacts with land cover and land use (i.e. the effect of climate warming on water generation 
depends on the amount of surface covered by natural vegetation and crops) and with population needs, and these have also changed over time. Nevertheless, in the lower areas of the rivers, water management and demand complement the observed changes in climate, but in the headwaters climatic changes have had the most significant effect on streamflow reduction between 1950 and 2013. Different studies suggested that a general revegetation in the Pyrenees (Lasanta and Vicente-Serrano, 2007; García-Ruiz and Lana-Renault, 2011) could be reducing runoff due to the increased evaporation and interception of precipitation (Llorens and Domingo, 2007). Thus, Beguería et al. (2003) estimated that the reduction of streamflow caused by the expansion of forested areas was 25\% for the period of 1955 to 2000 in the central Spanish Pyrenees. In the headwaters of the Noguera Pallaresa River, Buendía et al. (2014) estimated a decrease in streamflow of 7\% to 36\% from 1965 to 2009 due to changes in land use. Our application of two different methodologies (annual and monthly runoff coefficients and calculation of empirical models to predict streamflow based on climate data), indicated that climate was the main driver of streamflow changes during the study period in the headwaters. Nevertheless, the negative evolution of the runoff coefficient, mainly during summer months, suggests that increased vegetation coverage also contributed to the reduced streamflow. In any case, as with irrigated lands, the influence of changes in land cover are difficult to separate from changes in climate given the concurrent evolution toward warmer conditions and denser forest coverage, both of which lead to increased evapotranspiration.

The current water management scheme in the Segre Basin employs significant interventions to cope with the strong water demands from agriculture, but there are clearly uncertainties regarding the future. In particular, the observed climate changes in the basin have already compromised the model used for water management in this region. Moreover, the current pattern of water use is not sustainable for the near future because climate change scenarios forecast reduced precipitation and a large increase in atmospheric evaporative demand during the coming decades in the western Mediterranean region (Giorgi and Lionello, 2008), including the Segre Basin (Calbó et al., 2012). These changes will lead to more severe and more frequent climatic and hydrological droughts (Blenkinsop and Fowler, 2007; Forzieri et 
al., 2014). Other forecasts indicate that afforestation of the slopes will continue in the future (Lasanta et al., 2015). Therefore, given the most plausible scenarios, we expect that water availability will decline in the near future. Thus, it will be increasingly difficult or impossible to satisfy water demands using the current management strategy, making practically impossible the development of projects to transfer water from the Ebro basin to other regions of Southeast Spain (Albiac et al., 2006), and it will soon be necessary to adopt new water consumption and management strategies.

\section{Acknowledgements}

\section{7}

The authors thank AEMET and José C. González-Hidalgo, from University of Zaragoza, for providing climate data used in this study and Confederación Hidrográfica del Ebro for providing hydrological data. This work was supported by the research projects CGL2014-52135-C03-01, Red de variabilidad y cambio climático RECLIM (CGL2014-517221-REDT) financed by the Spanish Commission of Science and Technology and FEDER and "LIFE12 ENV/ES/000536-Demonstration and validation of innovative methodology for regional climate change adaptation in the Mediterranean area (LIFE MEDACC)” financed by the LIFE programme of the European Commission.

\section{References}

Albiac, J., Hanemann, M., Calatrava, J., Uche, J., Tapia, J., 2006. The rise and fall of the Ebro water transfer. Natural Resources Journal 46, 727-757.

Aus Der Beek, T. et al. 2010. Modelling historical and current irrigation water demand on the continental scale: Europe. Advances in Geosciences 27, 79-85.

Azorin-Molina, C., Vicente-Serrano, S.M., Sanchez-Lorenzo, A., McVicar, T.R., Morán-Tejeda, E., Revuelto, J., El Kenawy, A., Martín-Hernández, N., Tomas-Burguera, M., 2015. Atmospheric evaporative demand observations, estimates and driving factors in Spain (1961-2011). Journal of Hydrology 523, 262-277.

Barriendos, M., et al. 2003. Stationarity analysis of historical flood series in France and Spain (14th-20th centuries). Natural Hazards and Earth System Science 3, 583-592.

Batalla, R.J., Gómez, C.M., Kondolf, G.M., 2004. Reservoir-induced hydrological changes in the Ebro River basin NE Spain. J. Hydrol. 290, 117-136.

Beguería, S., López-Moreno, J.I., Lorente, A., Seeger, M., García-Ruiz, J.M., 2003. Assessing the effects of climate oscillations and land-use changes on streamflow in the Central Spanish Pyrenees. Ambio 32, 283-286. 
Blenkinsop, S., Fowler, H.J., 2007. Changes in European drought characteristics projected by the PRUDENCE regional climate models. International Journal of Climatology 27, 1595-1610.

Brunet, M., Jones, P.D., Sigro, J., Saladie, O., Aguilar, E., Moberg A., Della-Marta, P.M., Lister, D., Walther, A., López, D. 2007. Temporal and spatial temperature variability and change over Spain during 1850-2005. J Geophys Res 112:D12117. doi:10.1029/2006JD008249.

Buendía, C., Batalla, R.J., Sabater, S., Palau, A., Marcé, R., 2015. Runoff Trends Driven by Climate and Afforestation in a Pyrenean Basin. Land Degradation and Development. DOI: 10.1002/ldr.2384.

Buendía, C., et al., 2015b. Effects of afforestation on runoff and sediment load in an upland Mediterranean catchment, Sci Total Environ http://dx.doi.org/10.1016/j.scitotenv.2015.07.005

Calbó, J., Sanchez-Lorenzo, A., Barrera-Escoda, A., Cunillera, J., 2012. Climate change projections for Catalonia (NE Iberian Peninsula). Part II: Integrating several methodologies. Tethys 9, 13-24

Clop, M.M., Cots, L., Esteban, M., Barragán, J.D., 2009. Rentabilidad económica del regadío de los canales de Urgell (Lleida, España). ITEA Informacion Tecnica Economica Agraria 105, 36-48.

De Luis, M., González-Hidalgo, J.C., Brunetti, M., Longares, L.A., 2011. Precipitation concentration changes in Spain 1946-2005. Natural Hazards and Earth System Science 11, 1259-1265.

Döll, P., Fiedler, K., Zhang, J. 2009. Global-scale analysis of river flow alterations due to water withdrawals and reservoirs. Hydrology and Earth System Sciences 13, 2413-2432.

Duarte, R., Pinilla, V., Serrano, A., 2014. The water footprint of the Spanish agricultural sector: 18602010. Ecological Economics 108, 200-207.

Forzieri, G., Feyen, L., Rojas, R., 2014. Ensemble projections of future streamflow droughts in Europe. Hydrology and Earth System Sciences 18, 85-108

Gallart, F., Llorens, P., 2003. Observations on land cover changes and water resources in the headwaters of the Ebro catchment, Iberian Peninsula. Physics and Chemistry of the Earth 29, 769-773.

García-Garizábal, I., Causapé, J., Abrahao, R., Merchan, D. 2014. Impact of Climate Change on Mediterranean Irrigation Demand: Historical Dynamics of Climate and Future projections. Water Resources Management 28, 1449-1462.

García-Ruiz, J.M., López-Moreno, J.I., Vicente-Serrano, S.M., Lasanta, T., Beguería, S., 2011. Mediterranean water resources in a global change scenario. Earth Sciences Review 105, 121-139..

García-Ruiz, J.M., Lana-Renault, N., 2011. Hydrological and erosive consequences of farmland abandonment in Europe, with special reference to the Mediterranean region - A review. Agriculture, Ecosystems and Environment 140, 317-338.

Giorgi, F., Lionello, P., 2008. Climate change projections for the Mediterranean region. Global and Planetary Change 63, 90-104.

González-Hidalgo, J.C., Brunetti, M., de Luis, M. 2011. A new tool for monthly precipitation analysis in Spain: MOPREDAS database (monthly precipitation trends December 1945-November 2005). Int J Climatol 31, 715-731.

Gonzalez-Hidalgo, J.C., Peña-Angulo, D., Brunetti, M. and Cortesi, N. 2015. MOTEDAS: a new monthly temperature database for mainland Spain and the trend in temperature (1951-2010). Int. J. Climatol.. doi: 10.1002/joc.4298.

Hair, J.F., Anderson, R.E., Tatham, R.L., Black, W.C., 1998. Multivariate Data Analysis. Prentice Hall International, Inc.: New York; 799.

Hargreaves, G.L., Samani, Z.A., 1985. Reference crop evapotranspiration from temperature. Applied Engineering in Agriculture 1, 96-99.

Hoerling M et al. 2012. On the increased frequency of Mediterranean drought. J. Clim. 25, 2146-61. 
Iglesias, A., Minguez, M.I., 1997. Modelling crop-climate interactions in Spain, vulnerability and adaptation of different agricultural systems to climate change. Mitig. Adapt. Strat. Glob. Change 1, 273-288.

Kilic, S., Evrendilek, F., Berberoglu, S., Demirkesen, A.C., 2006. Environmental monitoring of land-use and land-cover changes in a Mediterranean Region of Turkey. Environmental Monitoring and Assessment 114, 157-168.

Lanzante, J.R. 1996. Resistant, robust and non-parametric techniques for the analysis of climate data: theory and examples, including applications to historical radiosonde station data. International Journal of Climatology 16, 1197-1226.

Lasanta, T., Vicente-Serrano, S.M., 2007. Cambios en la cubierta vegetal en el Pirineo aragonés en los últimos 50 años. Pirineos 162, 155-176.

Lasanta, T., Nadal-Romero, E., Arnáez, J., 2015. Managing abandoned farmland to control the impact of re-vegetation on the environment. The state of the art in Europe. Environmental Science and Policy 52, 99-109.

Lionello, P., 2012, The Climate of the Mediterranean Region. Elsevier.

Llorens, P., Domingo, F., 2007. Rainfall partitioning by vegetation under Mediterranean conditions. A review of studies in Europe. Journal of Hydrology 335, 37-54.

Lopez-Bustins, J.A., Pascual, D., Pla, E., Retana, J., 2013. Future variability of droughts in three Mediterranean catchments. Natural Hazards 69, 1405-1421.

López-Moreno, J.I., Beguería, S., García-Ruiz, J.M., 2004. The management of a large Mediterranean reservoir: Storage regimens of the Yesa Reservoir, Upper Aragon River basin, Central Spanish Pyrenees. Environmental Management 34: 508-515.

López-Moreno, J.I., Beniston, M., García-Ruiz, J.M., 2008. Environmental change and water management in the Pyrenees: Facts and future perspectives for Mediterranean mountains. Global and Planetary Change 61, 300-312.

López-Moreno, J.I., Vicente-Serrano, S.M., Beguería, S. García-Ruiz, J.M., Portela, M. M., Almeida, A. B., 2009. Downstream propagation of hydrological droughts in highly regulated transboundary rivers: the case of the Tagus River between Spain and Portugal. Water Resources Research 45, W02405, doi:10.1029/2008WR007198.

López-Moreno, J.I., Vicente-Serrano, S.M., Moran-Tejeda, E., Zabalza, J., Lorenzo-Lacruz, J., GarcíaRuiz, J.M., 2011. Impact of climate evolution and land use changes on water yield in the Ebro basin. Hydrology and Earth System Science 15, 311-322.

López-Moreno, J.I., Vicente-Serrano, S.M., Zabalza, J., Beguería, S., Lorenzo-Lacruz, J., Azorin-Molina, C., Morán-Tejeda, E., 2013. Hydrological response to climate variability at different time scales: a study in the Ebro basin. Journal of Hydrology 477, 175-188.

Lorenzo-Lacruz, J., Vicente-Serrano, S.M., López-Moreno, J.I., Beguería, S., García-Ruiz, J.M., Cuadrat, J.M., 2010. The impact of droughts and water management on various hydrological systems in the headwaters of the Tagus River (central Spain). Journal of Hydrology 386, 13-26.

Lorenzo-Lacruz, J., Vicente-Serrano, S.M., López-Moreno, J.I., Morán-Tejeda, E., Zabalza, J., 2012. Recent trends in Iberian streamflows (1945-2005). Journal of Hydrology 414-415, 463-475.

Lorenzo-Lacruz, J., Vicente-Serrano, S.M., González-Hidalgo, J.C., López-Moreno, J.I., Cortesi, N., 2013. Hydrological drought response to meteorological drought at various time scales in the Iberian Peninsula. Climate Research 58, 117-131.

March, H., Domènech, L., Saurí, D., 2013. Water conservation campaigns and citizen perceptions: The drought of 2007-2008 in the Metropolitan Area of Barcelona. Natural Hazards 65, 1951-1966. 
Martin-Ortega, J., González-Eguino, M., Markandya, A., 2012. The costs of drought: The 2007/2008 case of Barcelona. Water Policy 14, 539-560.

Matas, R., 2015. La doble cosecha de cereal, una realidad de cultivo en Lleida. Vida rural 400, 16-18.

Morán-Tejeda, E., Lorenzo-Lacruz, J., López-Moreno, J.I., Rahman, K., Beniston, M., 2014. Streamflow timing of mountain rivers in Spain: Recent changes and future projections Journal of Hydrology 517, 1114-1127

Ninyerola, M., Pons, X., Roure, J.M. 2000. A methodological approach of climatological modelling of air temperature and precipitation through GIS techniques. International Journal of Climatology 20, 1823-1841.

Paternoster, R., Brame, R., Mazerolle, P., Piquero, A.R. 1998. Using the Correct Statistical Test for the Equality of Regression Coefficients. Criminology 36, 859-866.

Pascual M. et al., 2006. Historia y situación actual de la fruticultura en Lleida. Fruticultura profesional, 158, 5-15.

Phillips, D.L., Dolph, J., Marks, D. 1992. A comparison of geostatistical procedures for spatial analysis of precipitation in mountainous terrain. Agric Meteorol 58, 119-141.

Pinilla, V., 2006. The development of irrigated agriculture in twentieth-century Spain: A case study of the Ebro basin. Agricultural History Review 54, 122-141.

Pons X., 2007. Manual of miramon. Geographic Information System and Remote Sensing Software. Centre de Recerca Ecol’ogica i Aplicacions Forestals (CREAF): Bellaterra, (http://www.creaf.uab.es/miramon).

Sacasas, J., 2007. Geografía de Catalunya, L’Abadia de Montserrat.

Thorndycraft, V.R., Barriendos, M., Benito, G., Rico, M., Casas, A., 2006. The catastrophic floods of AD 1617 in Catalonia (northeast Spain) and their climatic context. Hydrological Sciences Journal 51, 899-912.

Vicente-Serrano, S.M., Lanjeri, S. López-Moreno, J.I., 2007. Comparison of different procedures to map reference evapotranspiration using geographical information systems and regression-based techniques. International Journal of Climatology 27, 1103-118.

Vicente-Serrano, S.M., Lopez-Moreno, J.I., Beguería, S., Lorenzo-Lacruz, J., Sanchez-Lorenzo, A., García-Ruiz, J.M., Azorin-Molina, C., Revuelto, J., Trigo, R., Coelho, F., Espejo, F., 2014a. Evidence of increasing drought severity caused by temperature rise in southern Europe. Environmental Research Letters. 9, 044001. doi:10.1088/1748-9326/9/4/044001.

Vicente-Serrano, S.M., et al. 2014b. Reference evapotranspiration variability and trends in Spain, 19612011. Global and Planetary Change 121, 26-40.

Vicente-Serrano, S.M., et al. 2014c. Temporal evolution of surface humidity in Spain: recent trends and possible physical mechanisms. Climate Dynamics 42, 2655-2674

Vicente-Serrano, S.M., et al. 2014d. Sensitivity of reference evapotranspiration to changes in meteorological parameters in Spain (1961-2011), Water Resources Research 50, 8458-8480.

Viviroli, D., Weingartner, R., 2004. The hydrological significance of mountains: from regional to global scale. Hydrology and Earth System Sciences 8, 1016-1029.

Viviroli, D., Dürr, H.H., Messerli, B., Meybeck, M., Weingartner, R., 2007. Mountains of the worldwater towers for humanity: typology, mapping and global significance. Water Resources Research 43, W07447.

Willmott, C.J., 1981. On the validation of models. Phys Geogr 2: 184-194 


\section{Figure captions}

614 Figure 1. Location and topography of the Segre River Basin. The main reservoirs are in blue and the 615 black squares indicate the locations of gauging stations used in this study.

616 Figure 2. Changes in total reservoir capacity (red), water storage (blue), and the ratio between storage and 617 capacity (dark red) in the Segre Basin between 1951 and 2013.

618 Figure 3: Temporal evolution of the monthly Agreement index (D) (black) and MAE (red) for the gridded 619 layers of precipitation, maximum and minimum temperature. These statistics were obtained by means of 620 cross-validation.

621 Figure 4. Average monthly reservoir storage (white bars), inflow (blue lines), and release (red line) in the 622 six main reservoirs of the Segre Basin. The study period in 1950-2013 for Talarn and Camarasa, 19606232013 for Escales and Oliana, 1968-2103 for Canelles+Santa Ana and 2005-2013 for Rialb.

624 Figure 5. Changes in monthly inflow (blue), outflow (red), and reservoir storage (bars) in the five 625 reservoirs that have long data records. The year of data onset is indicated for those reservoirs constructed after 1950 and the changes were computed from the data onset to 2013. Circle (asterisk) indicate a statistically significant change $(\mathrm{p}<0.05)$ for streamflow (reservoir storage).

Figure 6. Seasonal and annual precipitation (left) and ETo (right) in the drainage basin of the gauging station at Seròs (1951-2013).

Figure 7. Seasonal and annual streamflow in the headwaters of the Segre River at Organyà (left) and the lower reaches of the Segre River at Seròs (right).

Figure 8. Monthly changes in streamflow at different gauging stations in the headwaters (black lines) and the lower reaches (red lines) in the Noguera Ribagorzana River and Pallaresa River (left panel) and the Segre River (right panel). Squares indicate statistically significant changes $(p<0.05)$.

Figure 9. Annual runoff coefficient in the rivers at gauging stations upstream (top) and downstream (bottom) of the main reservoirs.

Figure 10. Detrended ETo (red) and in the detrended annual runoff coefficient (blue) in the Seròs and Balaguer stations.

Figure 11. Observed streamflow during July in the Segre River at the station of Seròs and predicted streamflow based on the climatic data.

Figure 12. Observed percentage change in monthly streamflow from 1951 to 2013, and predicted percentage change according to climatic changes alone. Asterisk indicates a statistically significant difference $(\mathrm{p}<0.05)$ between observed and predicted changes.

Figure 13. Average monthly water extraction for irrigation in the basin (top) and changes in total summer flows in the d'Urgell canal (bottom) from 1958 to 2012. 
Table 1. Percent change in monthly and annual precipitation and reference evapotranspiration (ETo) from 1951 to 2013 in the eight analyzed drainage basins. asterisk indicates statistically significant trends ( $p<$ 0.05). Blue: non-regulated basin; orange: regulated basin.

\begin{tabular}{|c|c|c|c|c|c|c|c|c|c|c|c|c|c|c|c|c|}
\hline & \multicolumn{8}{|c|}{ Precipitation } & \multicolumn{8}{|c|}{ ETo } \\
\hline & Pont de Suert & La P. Segur & Pinyana & Puigcerdà & Organyà & Oliana & Balaguer & Seròs & Pont de Suert & La P. Segur & Pinyana & Puigcerdà & Organyà & Oliana & Balaguer & Seròs \\
\hline Jan & 33.4 & 37.7 & 44.1 & 41.4 & 38.2 & 38.7 & 38.6 & 44.4 & $7.5^{*}$ & 5.3 & $9.1^{*}$ & 10.3 & $11.5^{*}$ & $11.5^{*}$ & 8.0 & 8.8 \\
\hline Feb & -41.9 & -45.4 & -25.7 & -38.8 & -43.5 & -43.3 & -39.9 & -30.8 & 8.9 & 9.1 & 10.5 & 11.4 & 12.7 & 12.6 & 13.9 & 13.1 \\
\hline Mar & -46.6 & -45.2 & -39.1 & -36.5 & -42.3 & -42.1 & -39.9 & -34.8 & $9.6^{*}$ & $8.6^{*}$ & $10.9^{*}$ & $13.6^{*}$ & $13.3^{*}$ & $13.3^{*}$ & $11.1^{*}$ & $11.7^{*}$ \\
\hline Apr & 15.1 & 19.7 & 27.3 & 10.8 & 12.6 & 13.2 & 20.8 & 27.5 & 4.6 & 3.9 & 5.3 & 7.6 & 7.2 & 7.1 & 6.8 & 6.7 \\
\hline May & -25.8 & -23.9 & -23.9 & -26.7 & -25.1 & -24.9 & -22.5 & -18.7 & 3.1 & 2.0 & 3.1 & 7.7 & 5.0 & 4.9 & 2.6 & 1.8 \\
\hline Jun & $-55.2^{*}$ & $-52.6^{*}$ & $-57.8^{*}$ & $-54.7^{*}$ & $-54.6^{*}$ & $-54.8^{*}$ & $-55.2^{*}$ & $-55.7^{*}$ & $12.3^{*}$ & $12.0^{*}$ & $13.0^{*}$ & $17.7^{*}$ & $16.2^{*}$ & $16.2^{*}$ & $13.7^{*}$ & $12.8^{*}$ \\
\hline Jul & $-41.3^{*}$ & $-41.1^{*}$ & $-39.6 *$ & $-45.4^{*}$ & $-41.9 *$ & $-41.5^{*}$ & $-39.3^{*}$ & $-37.2^{*}$ & $5.3^{*}$ & $5.5^{*}$ & $6.0^{*}$ & $10.5^{*}$ & $8.4^{*}$ & $8.4^{*}$ & $6.2^{*}$ & $6.2^{*}$ \\
\hline Aug & $-44.2^{*}$ & $-42.6^{*}$ & $-44.0^{*}$ & $-41.8^{*}$ & $-42.9^{*}$ & $-42.5^{*}$ & $-40.3^{*}$ & $-38.0 *$ & $9.1^{*}$ & $8.9 *$ & $10.0^{*}$ & $14.8^{*}$ & $12.8^{*}$ & $12.8^{*}$ & $10.0^{*}$ & $9.4^{*}$ \\
\hline Sep & -22.4 & -22.6 & -25.5 & -32.2 & -27.2 & -27.1 & -25.6 & -27.1 & 3.4 & 2.8 & 3.9 & $10.0^{*}$ & 5.9 & 5.8 & 2.1 & 1.4 \\
\hline Oct & 27.7 & 24.8 & 36.0 & -12.8 & 4.1 & 5.2 & 15.9 & 21.7 & 4.3 & 3.0 & 4.7 & $11.7^{*}$ & 6.4 & 6.2 & 2.0 & 1.7 \\
\hline Nov & -20.9 & -15.3 & -6.4 & -7.3 & -8.4 & -7.3 & -3.0 & 3.5 & 1.3 & -0.6 & 2.1 & 0.5 & 2.6 & 2.6 & -0.7 & 1.0 \\
\hline Dec & -10.3 & -11.3 & 7.3 & -4.3 & -9.2 & -8.9 & -7.2 & -3.2 & 3.5 & 1.2 & 5.1 & $8.8^{*}$ & $7.9^{*}$ & $7.7^{*}$ & 4.9 & 6.5 \\
\hline Annual & $-22.7^{*}$ & $-21.8^{*}$ & $-16.6^{*}$ & $-24.8^{*}$ & $-23.7^{*}$ & $-23.4^{*}$ & $-20.1^{*}$ & $-16.2^{*}$ & $6.5^{*}$ & $6.0^{*}$ & $7.2^{*}$ & $11.4^{*}$ & $9.6^{*}$ & $9.5^{*}$ & $7.1^{*}$ & $6.8^{*}$ \\
\hline
\end{tabular}


651 Table 2. Percent change in monthly and annual streamflow from 1951 to 2013 in the eight analyzed 652 drainage basins. * indicate significant trends $(p<0.05)$. Blue: non-regulated basin; orange: regulated basin.

\begin{tabular}{|l|r|r|r|r|r|r|r|r|}
\hline & Pont de Suert & La P. Segur & Pinyana & Puigcerdà & Organyà & Oliana & Seròs & Balaguer \\
\hline Jan & 11.8 & -15.3 & $-75.6^{*}$ & $-22.0^{*}$ & -0.4 & $-19.8^{*}$ & $-51.1^{*}$ & $-79.0^{*}$ \\
\hline Feb & 0.4 & -29.8 & $-84.3^{*}$ & $-44.2^{*}$ & $-30.3^{*}$ & $-38.0^{*}$ & $-64.4^{*}$ & $-92.0^{*}$ \\
\hline Mar & -22.6 & -17.9 & $-81.6^{*}$ & -27.5 & $-31.5^{*}$ & $-39.5^{*}$ & $-72.0^{*}$ & $-97.7^{*}$ \\
\hline Apr & -15.2 & 3.7 & $-66.7^{*}$ & -25.6 & -23.6 & $-36.5^{*}$ & $-60.9^{*}$ & $-98.0^{*}$ \\
\hline May & $-15.4^{*}$ & 1.9 & $-69.3^{*}$ & -6.3 & -6.7 & -2.6 & $-48.5^{*}$ & $-72.8^{*}$ \\
\hline Jun & $-38.5^{*}$ & -15.3 & $-63.4^{*}$ & $-36.2^{*}$ & $-31.9^{*}$ & $-41.2^{*}$ & $-69.0^{*}$ & $-87.1^{*}$ \\
\hline Jul & $-50.3^{*}$ & $-33.0^{*}$ & $-49.3^{*}$ & $-54.3^{*}$ & $-53.1^{*}$ & $-38.6^{*}$ & $-73.6^{*}$ & $-96.1^{*}$ \\
\hline Aug & $-45.1^{*}$ & $-28.8^{*}$ & -26.4 & $-50.1^{*}$ & $-50.2^{*}$ & $-33.0^{*}$ & $-53.6^{*}$ & $-95.3^{*}$ \\
\hline Sep & $-48.3^{*}$ & $-33.3^{*}$ & $-42.8^{*}$ & $-63.7^{*}$ & $-47.3^{*}$ & $-57.0^{*}$ & $-49.8^{*}$ & $-98.2^{*}$ \\
\hline Oct & -41.8 & -34.5 & $-77.9^{*}$ & $-53.4^{*}$ & -35.7 & $-63.5^{*}$ & $-73.7^{*}$ & $-97.8^{*}$ \\
\hline Nov & -33.9 & -25.1 & $-84.6^{*}$ & $-39.9^{*}$ & -26.9 & $-34.6^{*}$ & $-61.6^{*}$ & $-82.6^{*}$ \\
\hline Dec & 5.5 & -23.9 & $-87.1^{*}$ & $-33.1^{*}$ & $-23.2^{*}$ & $-35.3^{*}$ & $-60.9^{*}$ & $-78.5^{*}$ \\
\hline Annual & $-28.2^{*}$ & -16.7 & $-67.6^{*}$ & $-32.8^{*}$ & $-27.6^{*}$ & $-34.6^{*}$ & $-61.8^{*}$ & $-91.3^{*}$ \\
\hline
\end{tabular}


Table 3. Percent change in the ratio of streamflow to monthly cumulative precipitation . asterisk indicates significant trends $(p<0.05)$. In parenthesis is included the precipitation cumulative period $n$ that shows the highest correlations with streamflow. Blue: non-regulated basin; orange: regulated basin.

\begin{tabular}{|l|r|r|r|r|r|r|r|l|}
\hline & $\begin{array}{l}\text { Pont de } \\
\text { Suert }\end{array}$ & $\begin{array}{l}\text { La P. } \\
\text { Segur }\end{array}$ & Pinyana & Puigcerdà & Organyà & Oliana & Balaguer & Seròs \\
\hline Jan & & -17.05 & $-69.24^{*}$ & -18.84 & -10.32 & & $-89.47^{*}$ & \\
& $-41.7(2)$ & $(2)$ & $(10)$ & $(1)$ & $(2)$ & $-36.9^{*}(4)$ & $(4)$ & $-49.62^{*}(5)$ \\
\hline Feb & $19.73^{*}$ & -16.77 & $-78.27^{*}$ & -28.05 & -20.15 & $-28.68^{*}$ & $-94.28^{*}$ & \\
& $(3)$ & $(3)$ & $(10)$ & $(3)$ & $(3)$ & $(3)$ & $(3)$ & $-58.66^{*}(5)$ \\
\hline Mar & -14.29 & 2.71 & $-71.68^{*}$ & & -15.46 & $-27.14^{*}$ & $-97.5^{*}$ & \\
& $(3)$ & $(5)$ & $(11)$ & $-5.65(5)$ & $(5)$ & $(5)$ & $(5)$ & $-66.52^{*}(8)$ \\
\hline Apr & 11.85 & 20.66 & $-57.18^{*}$ & -10.17 & -10.45 & & $-93.4^{*}$ & \\
& $(1)$ & $(5)$ & $(12)$ & $(6)$ & $(3)$ & $-27.22^{*}(3)$ & $(6)$ & $-58.68^{*}(8)$ \\
\hline May & & 16.63 & $-57.37^{*}$ & 7.83 & & & $-63.11^{*}$ & \\
& $-2.84(7)$ & $(7)$ & $(12)$ & $(12)$ & $5.96(7)$ & $15.42(7)$ & $(7)$ & $-43.34^{*}(12)$ \\
\hline Jun & $-18.04^{*}$ & 11.73 & $-38.06^{*}$ & -24.7 & -13.75 & $-26.81^{*}$ & $-83.17^{*}$ & \\
& $(6)$ & $(8)$ & $(11)$ & $(12)$ & $(5)$ & $(8)$ & $(8)$ & $-59.72^{*}(12)$ \\
\hline Jul & $-31.51^{*}$ & -7.06 & -15.94 & $-42.74^{*}$ & $-36.06^{*}$ & & $-96.2^{*}$ & \\
& $(6)$ & $(8)$ & $(12)$ & $(7)$ & $(7)$ & $-15.73(7)$ & $(3)$ & $-63.78^{*}(6)$ \\
\hline Aug & & -1.52 & & & $-26.6^{*}$ & & $-93.8^{*}$ & \\
& $5.75(5)$ & $(8)$ & $23.13(4)$ & $70.3(5)$ & $(5)$ & $-6.96(5)$ & $(4)$ & $-43.94^{*}(5)$ \\
\hline Sep & & 72.85 & & -27.43 & & $-39.66^{*}$ & $-99.47^{*}$ & \\
& $5.44(6)$ & $(6)$ & $-21.7(5)$ & $(6)$ & $4.77(6)$ & $(6)$ & $(6)$ & $-28.28^{*}(6)$ \\
\hline Oct & $-26.51^{*}$ & -16.66 & $-65.24^{*}$ & $-48.24^{*}$ & -20.36 & $-38.39^{*}$ & $-94.23^{*}$ & \\
& $(7)$ & $(7)$ & $(6)$ & $(7)$ & $(7)$ & $(7)$ & $(6)$ & $-57.1^{*}(7)$ \\
\hline Nov & -18.57 & -6.37 & $-71.73^{*}$ & $-27.17^{*}$ & $(1)$ & $-27.45^{*}$ & $-89.49^{*}$ & \\
& $(5)$ & $(10)$ & $(7)$ & $(1)$ & $-12(8)$ & $(8)$ & $(7)$ & $-57.46^{*}(12)$ \\
\hline Dec & & -5.11 & $-80.25^{*}$ & $-24.29^{*}$ & $(2)$ & $-25.17^{*}$ & $-85.01^{*}$ & \\
& $-1.23(3)$ & $(2)$ & $(11)$ & $(2)$ & $-12.3(2)$ & $(11)$ & $(8)$ & $-53.51^{*}(8)$ \\
\hline
\end{tabular}


660 Table 4. Correlations between de-trended monthly ratios of streamflow to precipitation with de-trended 661 ETo in each basin. * indicate significant trends $(p<0.05)$. Blue: non-regulated basin; orange: regulated basin.

\begin{tabular}{|r|r|r|r|r|r|r|r|r|}
\hline & Pont de Suert & La P. Segur & Pinyana & Puigcerdà & Organyà & Oliana & Balaguer & Seròs \\
\hline Jan & 0.14 & 0.21 & -0.23 & $-0.33^{*}$ & $-0.48^{*}$ & $-0.40^{*}$ & $-0.31^{*}$ & -0.19 \\
\hline Feb & 0.21 & -0.18 & $-0.33^{*}$ & $-0.33^{*}$ & $-0.31^{*}$ & $-0.26^{*}$ & $-0.27^{*}$ & -0.21 \\
\hline Mar & 0.10 & $0.31^{*}$ & -0.12 & $0.29^{*}$ & $0.29^{*}$ & 0.11 & -0.21 & -0.22 \\
\hline Apr & 0.16 & $0.30^{*}$ & -0.11 & -0.15 & -0.23 & $-0.31^{*}$ & -0.08 & $-0.27^{*}$ \\
\hline May & $0.38^{*}$ & 0.25 & 0.24 & $-0.37^{*}$ & $0.33^{*}$ & $-0.32^{*}$ & $-0.32^{*}$ & $-0.29^{*}$ \\
\hline Jun & $-0.32^{*}$ & $-0.36^{*}$ & $0.35^{*}$ & $-0.48^{*}$ & $-0.65^{*}$ & $-0.62^{*}$ & $-0.57^{*}$ & $-0.53^{*}$ \\
\hline Jul & $-0.27^{*}$ & $-0.35^{*}$ & 0.23 & -0.24 & $-0.41^{*}$ & 0.12 & $-0.46^{*}$ & $-0.40^{*}$ \\
\hline Aug & -0.11 & $-0.49^{*}$ & 0.15 & -0.17 & $-0.51^{*}$ & 0.20 & $-0.33^{*}$ & $-0.33^{*}$ \\
\hline Sep & -0.20 & -0.18 & 0.24 & $-0.41^{*}$ & $-0.30^{*}$ & $-0.35^{*}$ & $-0.45^{*}$ & $-0.33^{*}$ \\
\hline Oct & 0.21 & -0.21 & -0.20 & -0.08 & 0.08 & $-0.30^{*}$ & $-0.38^{*}$ & -0.17 \\
\hline Nov & -0.10 & $-0.26^{*}$ & -0.21 & $-0.45^{*}$ & $-0.26^{*}$ & $-0.25^{*}$ & $-0.34^{*}$ & -0.20 \\
\hline Dec & $-0.29 *$ & $-0.40^{*}$ & -0.21 & $-0.29 *$ & $-0.33^{*}$ & -0.21 & $-0.39^{*}$ & $-0.30^{*}$ \\
\hline
\end{tabular}


Table 5. Percentage of variance in monthly streamflow explained by climatic variables. Blue: nonregulated basin; orange: regulated basin.

\begin{tabular}{|r|r|r|r|r|r|r|r|r|}
\hline & Pont de Suert & La P. Segur & Pinyana & Puigcerdà & Organyà & Oliana & Balaguer & Seròs \\
\hline 1 & 51 & 66 & 36 & 49 & 58 & 63 & 48 & 53 \\
\hline 2 & 55 & 54 & 42 & 48 & 58 & 47 & 39 & 48 \\
\hline 3 & 50 & 48 & 34 & 29 & 47 & 46 & 43 & 48 \\
\hline 4 & 29 & 29 & 26 & 36 & 51 & 52 & 48 & 56 \\
\hline 5 & 45 & 30 & 20 & 35 & 44 & 50 & 50 & 51 \\
\hline 6 & 54 & 42 & 24 & 46 & 70 & 63 & 67 & 68 \\
\hline 7 & 43 & 47 & 37 & 36 & 54 & 29 & 53 & 50 \\
\hline 8 & 37 & 62 & 38 & 29 & 70 & 31 & 36 & 57 \\
\hline 9 & 48 & 45 & 37 & 55 & 55 & 53 & 45 & 57 \\
\hline 10 & 58 & 62 & 39 & 58 & 68 & 59 & 47 & 61 \\
\hline 12 & 58 & 66 & 38 & 65 & 69 & 70 & 50 & 51 \\
\hline
\end{tabular}



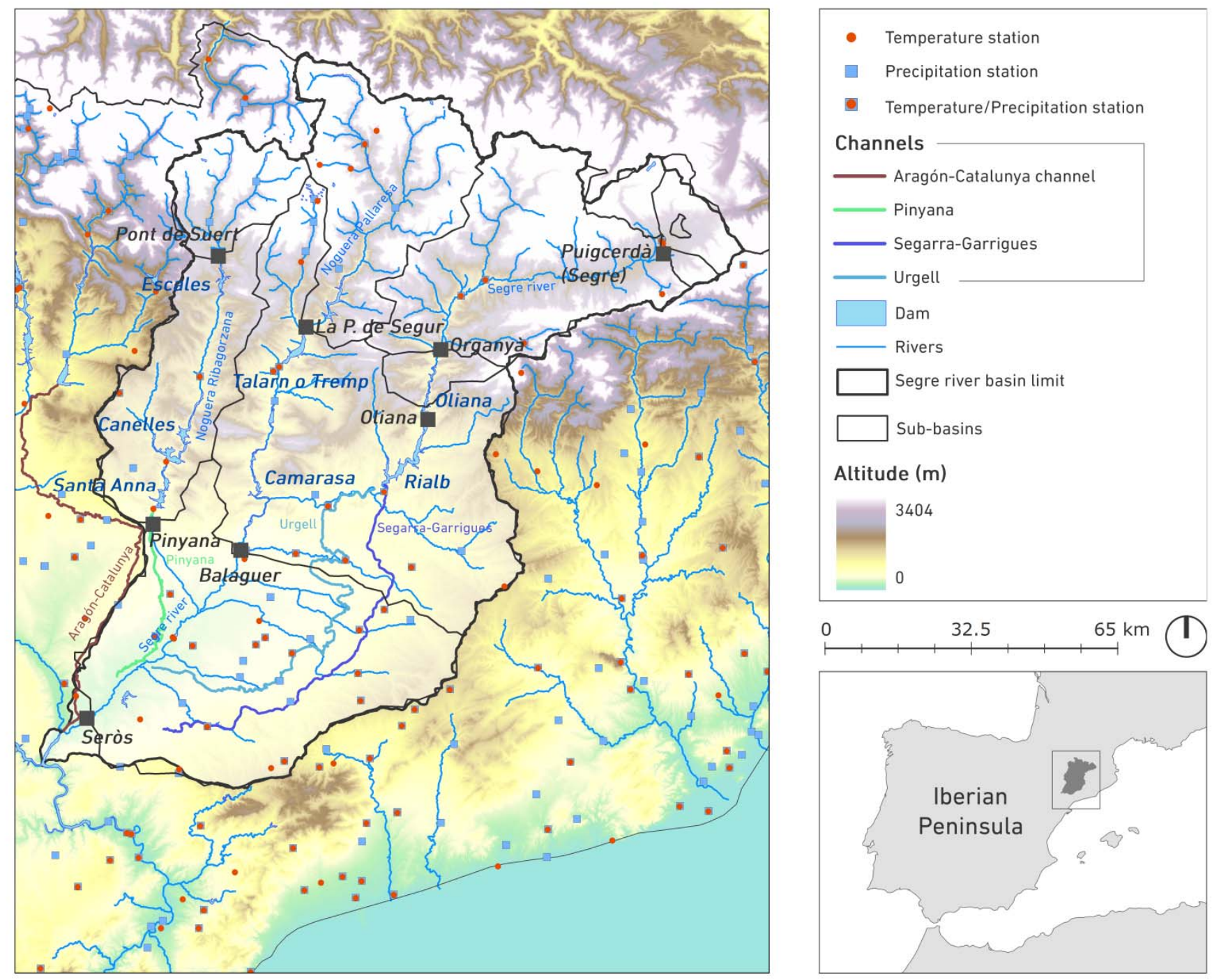

671 Figure 1. Location and topography of the Segre River Basin. The main reservoirs are in blue and the 672 black squares indicate the locations of gauging stations used in this study. 

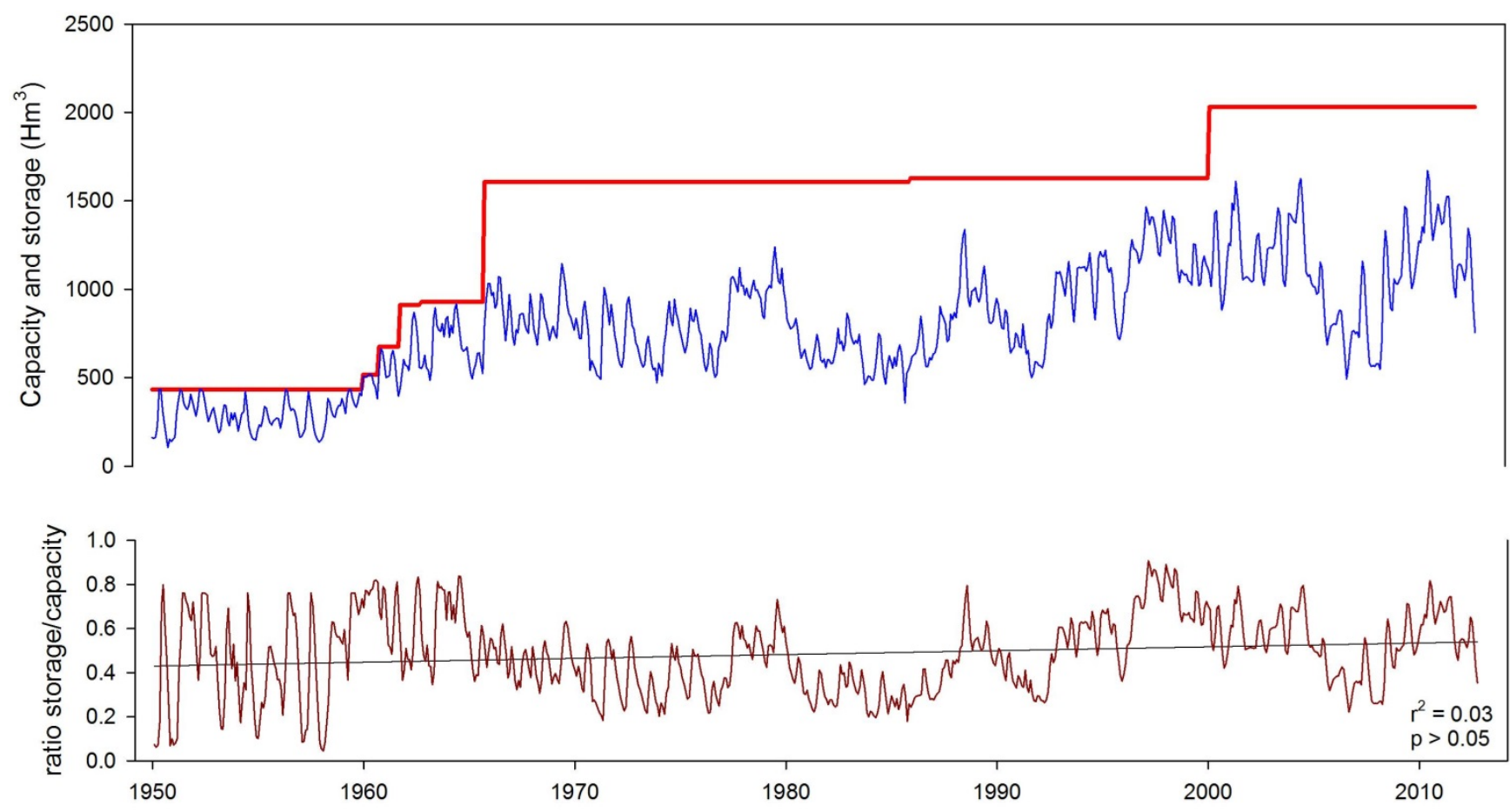

675 Figure 2. Changes in total reservoir capacity (red), water storage (blue), and the ratio between storage and 676 capacity (dark red) in the Segre Basin between 1950 and 2013. 

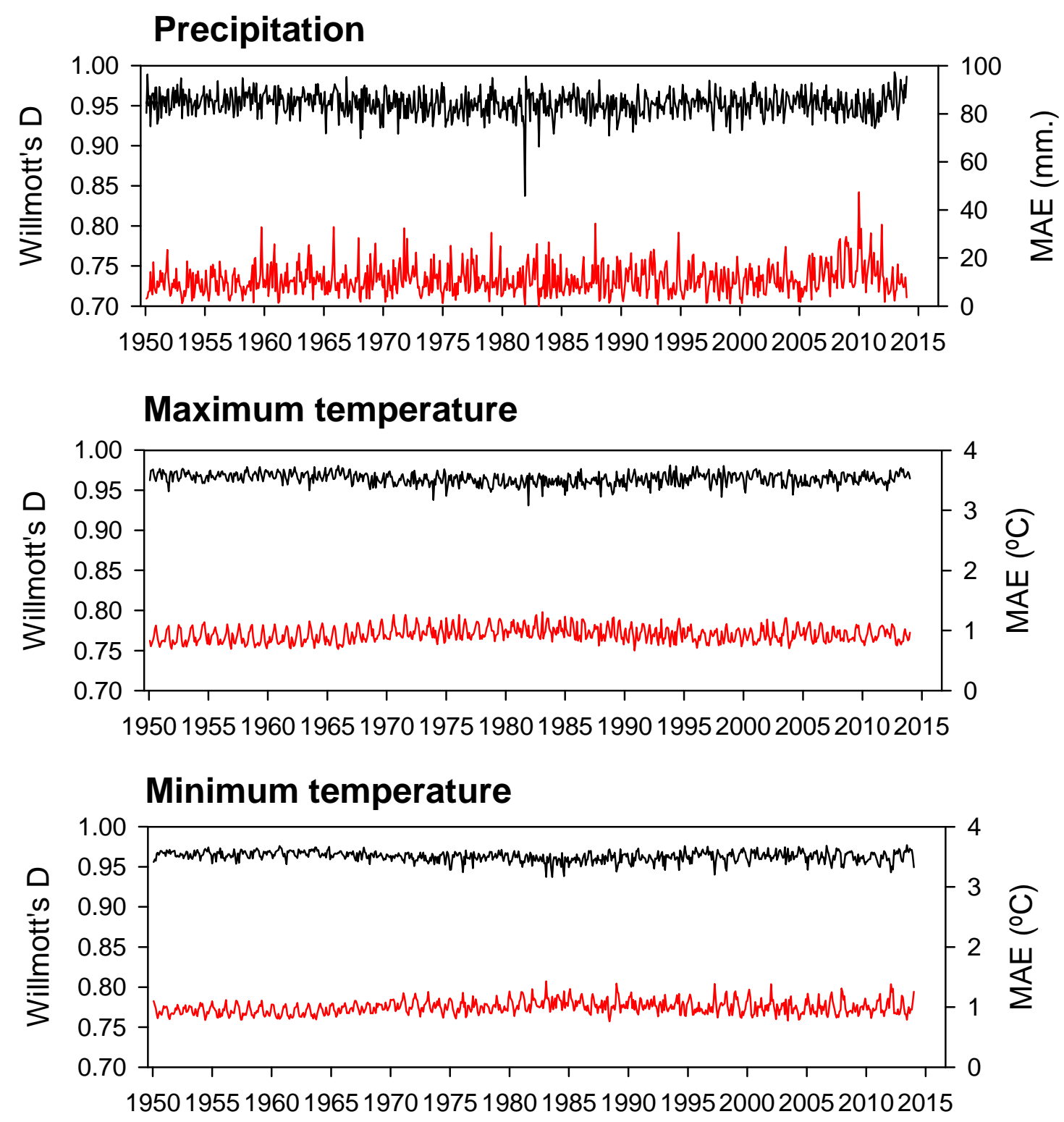

679 Figure 3: Temporal evolution of the monthly Agreement index (D) (black) and MAE (red) for the gridded 680 layers of precipitation, maximum and minimum temperature. These statistics were obtained by means of 681 cross-validation. 

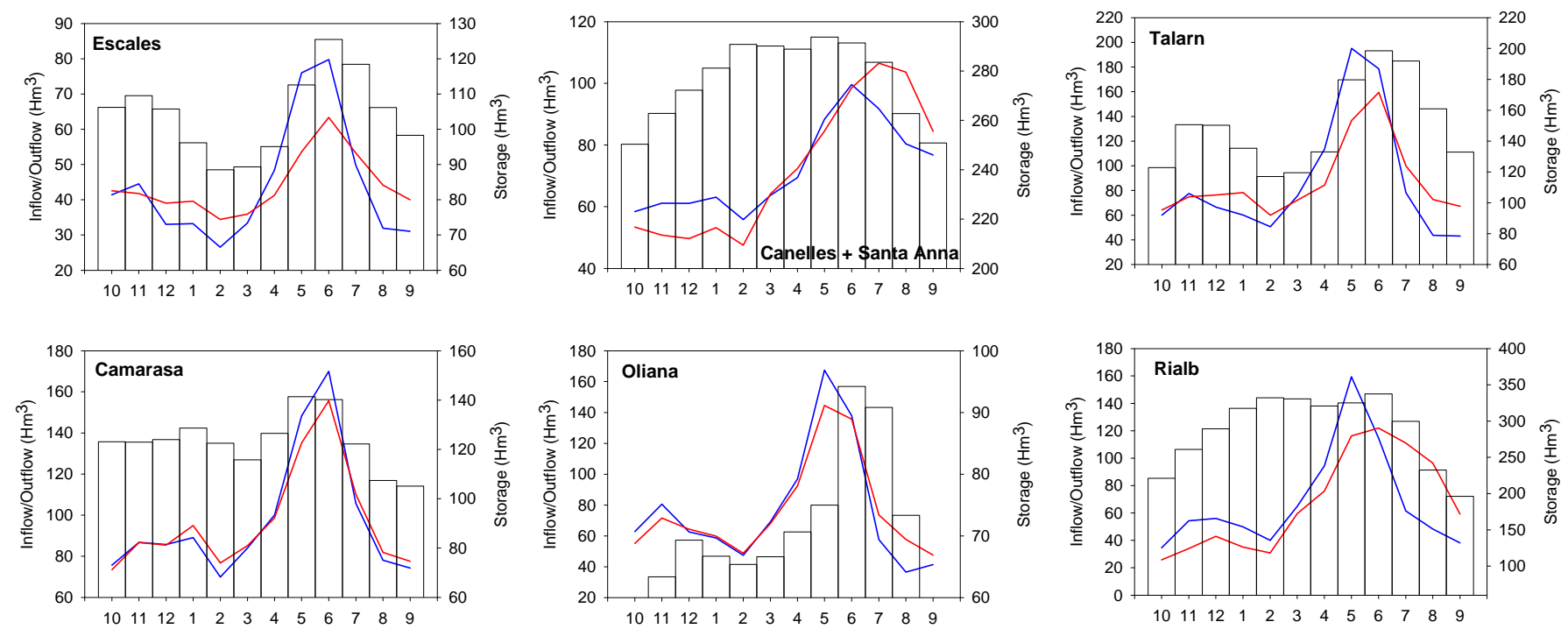

687 Figure 4. Average monthly reservoir storage (white bars), inflow (blue lines), and release (red line) in the 688 six main reservoirs of the Segre Basin. The study period in 1950-2013 for Talarn and Camarasa, 19606892013 for Escales and Oliana, 1968-2103 for Canelles+Santa Ana and 2005-2013 for Rialb. 

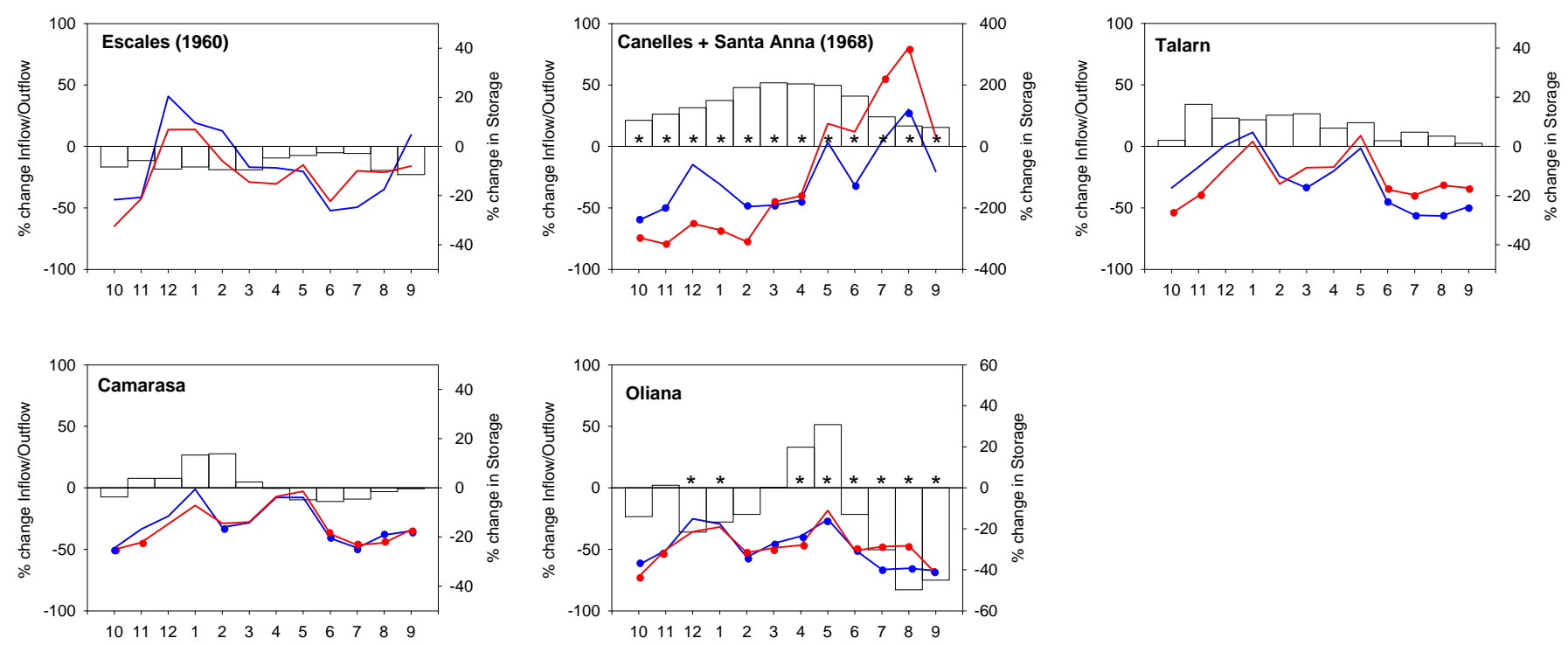

693 Figure 5. Changes in monthly inflow (blue), outflow (red), and reservoir storage (bars) in the five 694 reservoirs that have long data records. The year of data onset is indicated for those reservoirs constructed 695 after 1950 and the changes were computed from the data onset to 2013. Circle (asterisk) indicate a 696 statistically significant change $(\mathrm{p}<0.05)$ for streamflow (reservoir storage). 

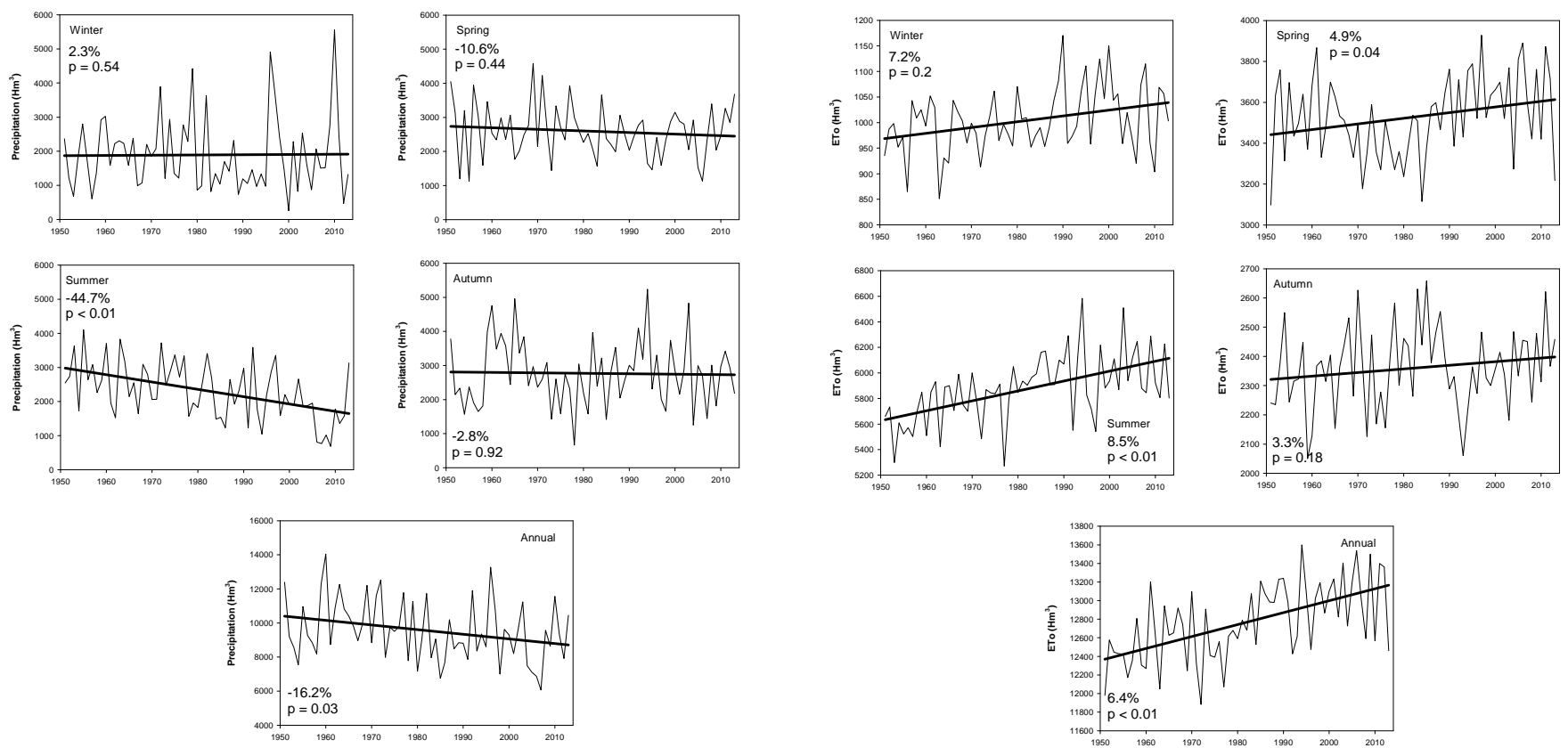

Figure 6. Seasonal and annual precipitation (left) and ETo (right) in the drainage basin of the gauging 701 station at Seròs (1951-2013). 

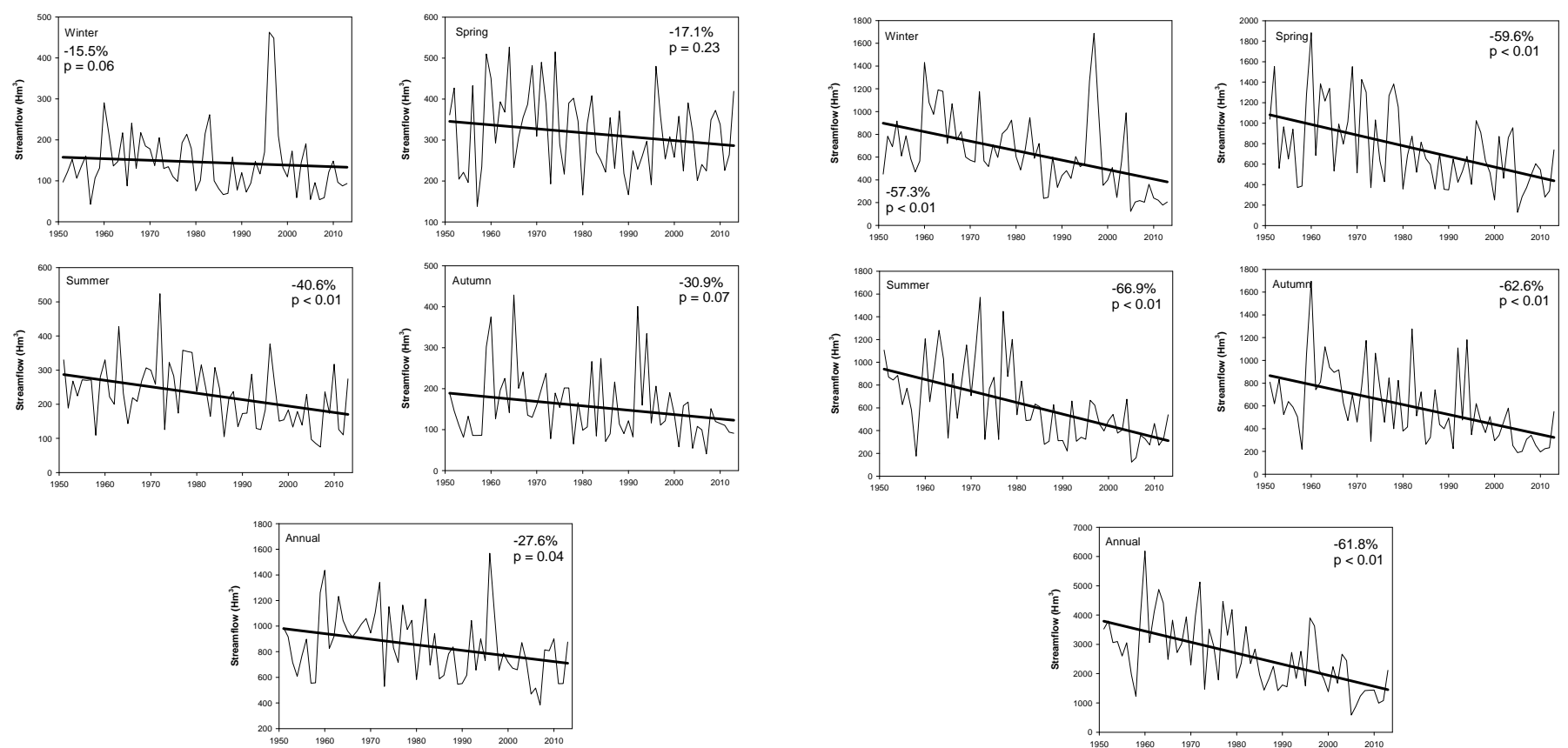

704 Figure 7. Seasonal and annual streamflow in the headwaters of the Segre River at Organyà (left) and the 705 lower reaches of the Segre River at Seròs (right). 

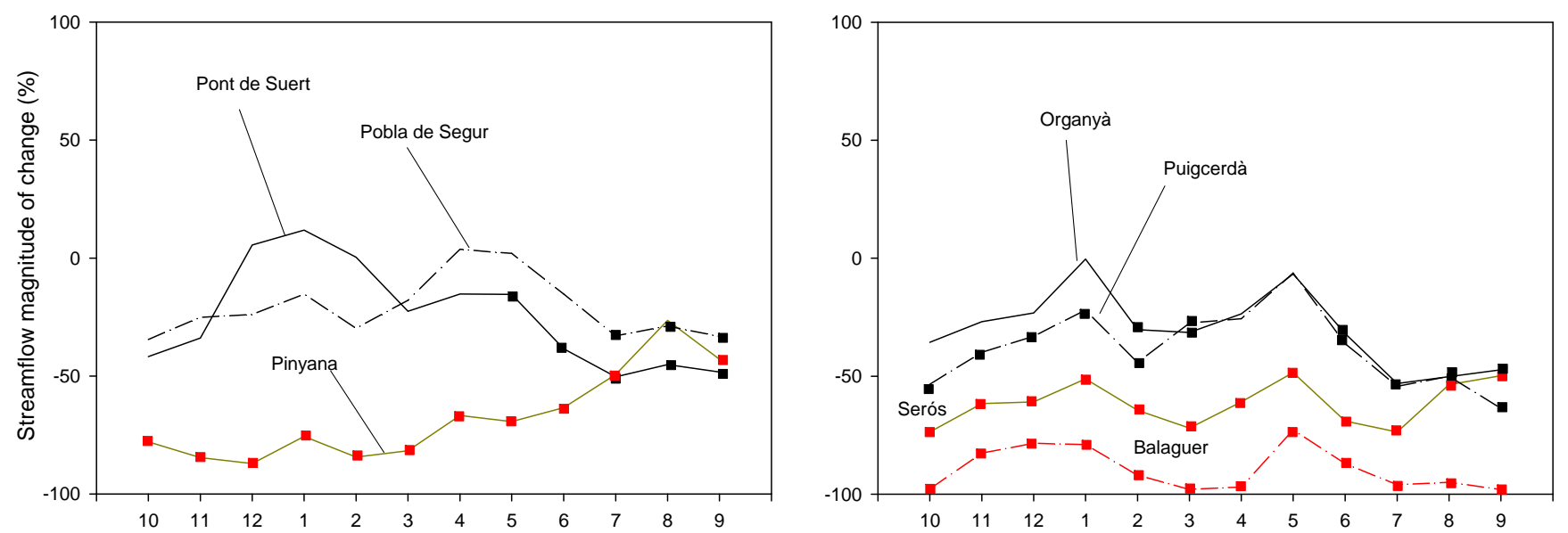

Figure 8. Monthly changes in streamflow at different gauging stations in the headwaters (black lines) and the lower reaches (red lines) in the Noguera Ribagorzana River and Pallaresa River (left panel) and the Segre River (right panel). Squares indicate statistically significant changes $(p<0.05)$. 

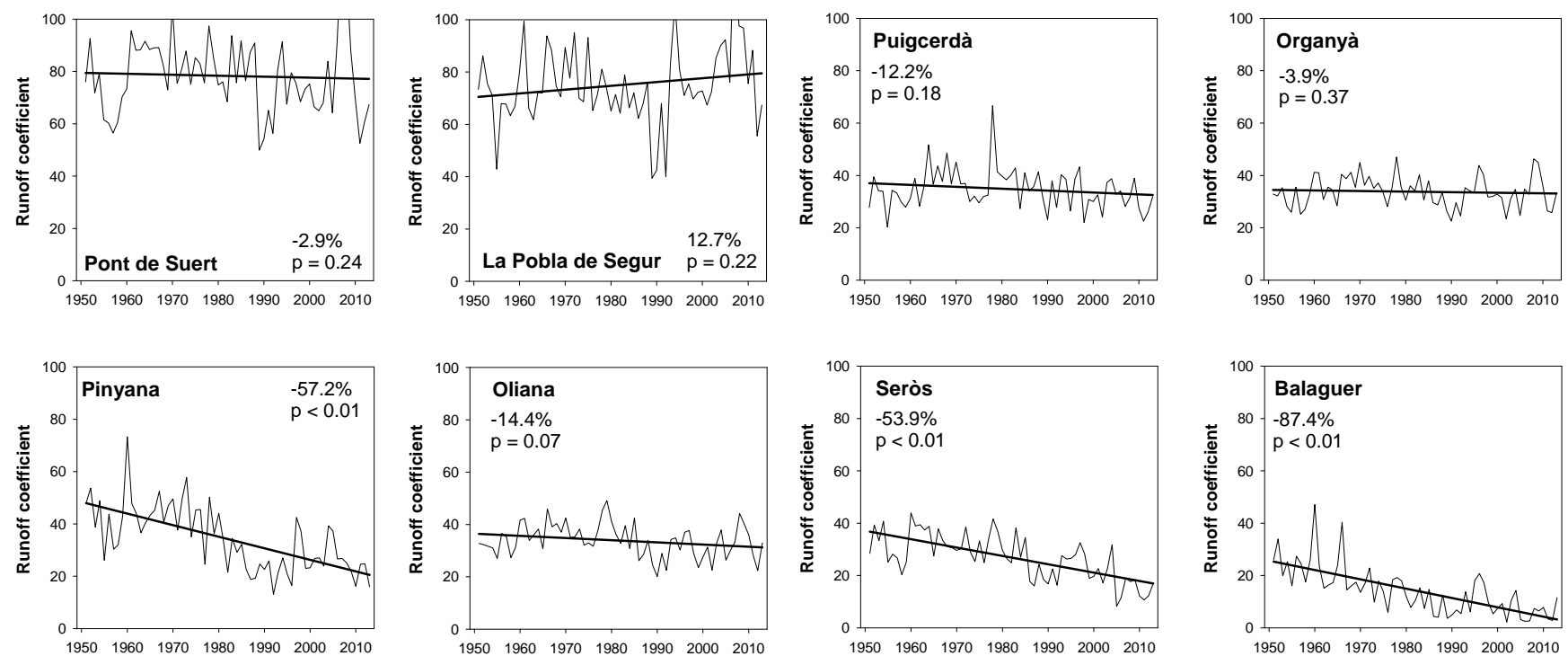

714 Figure 9. Annual runoff coefficient in the rivers at gauging stations upstream (top) and downstream 715 (bottom) of the main reservoirs. 

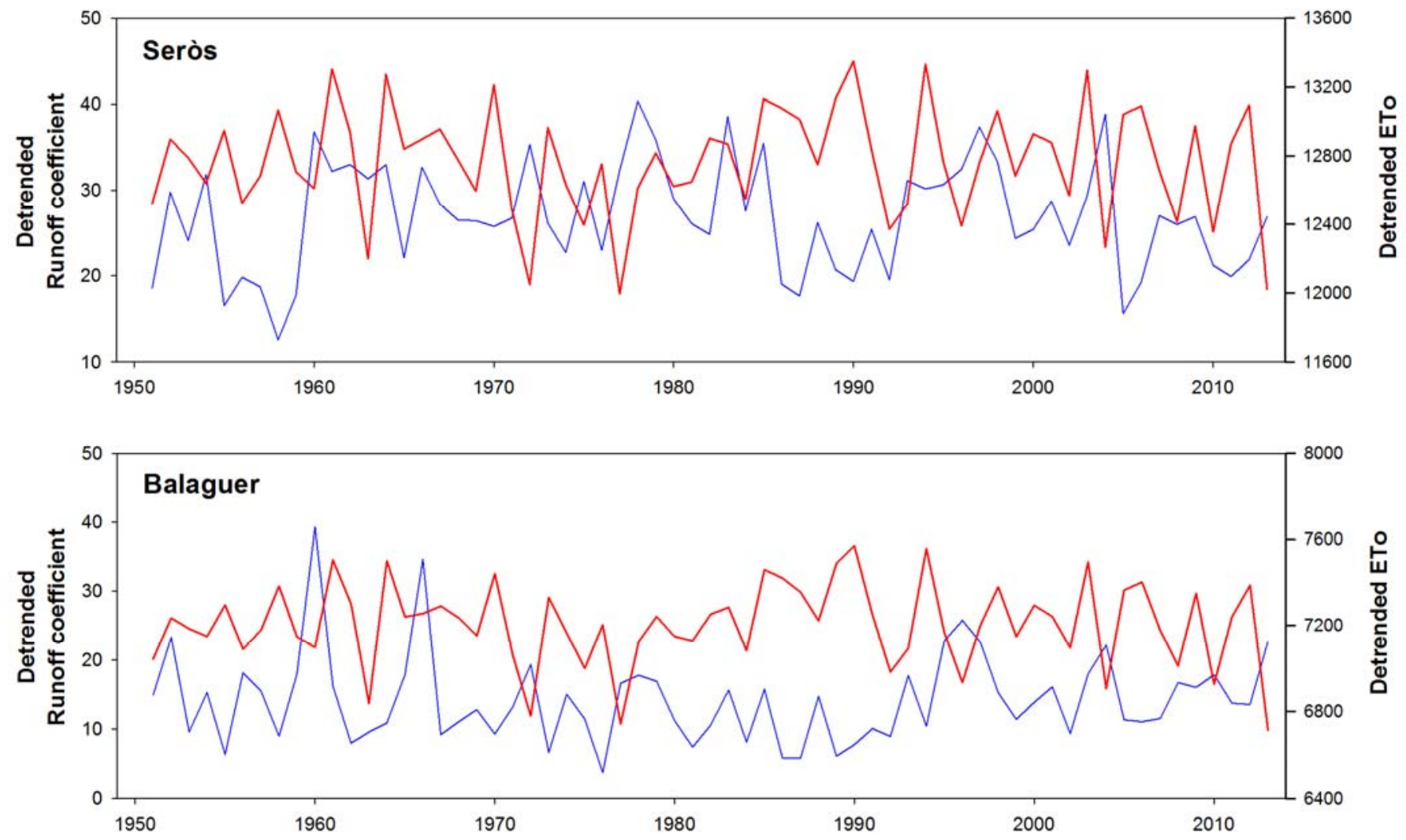

718 Figure 10. Detrended annual runoff coefficient (blue) and detrended ETo (red) in the Seròs and Balaguer 719 stations. 


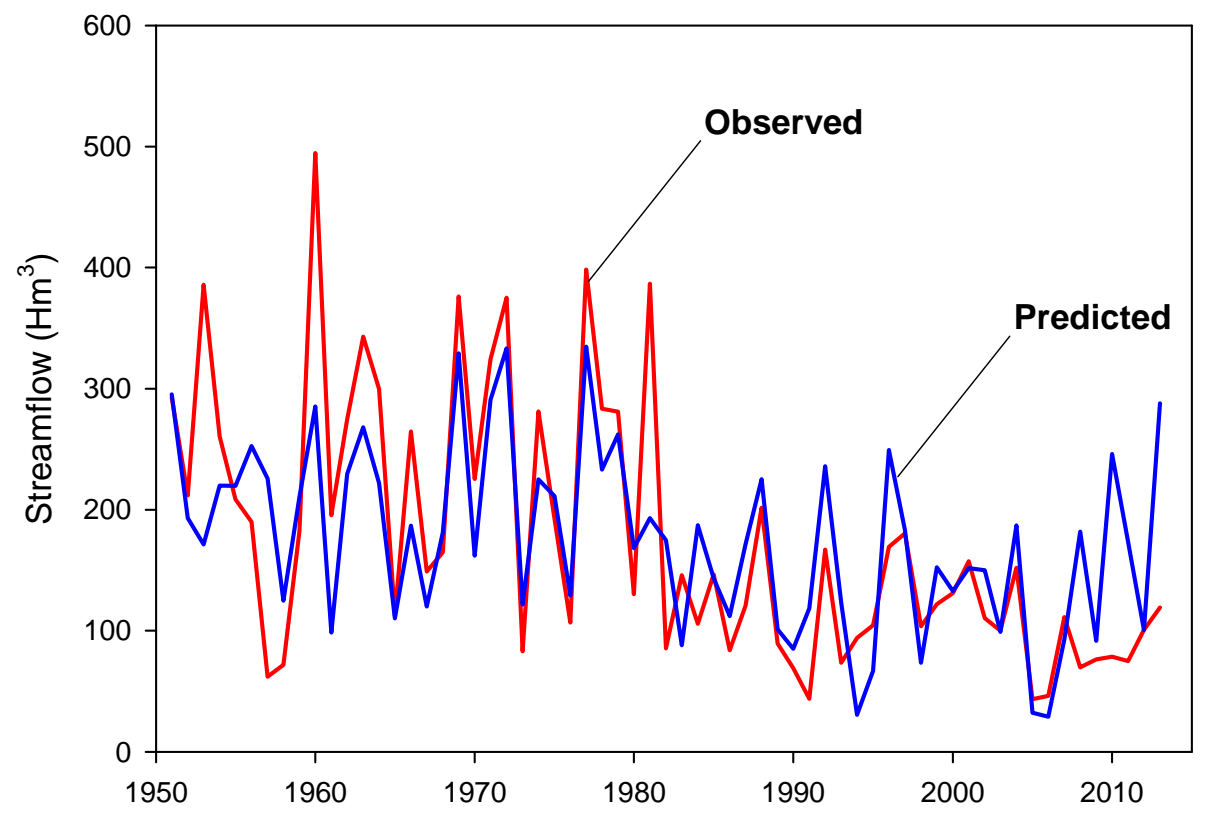

722 Figure 11. Observed streamflow during July in the Segre River at the station of Seròs and predicted 723 streamflow based on climatic data. 

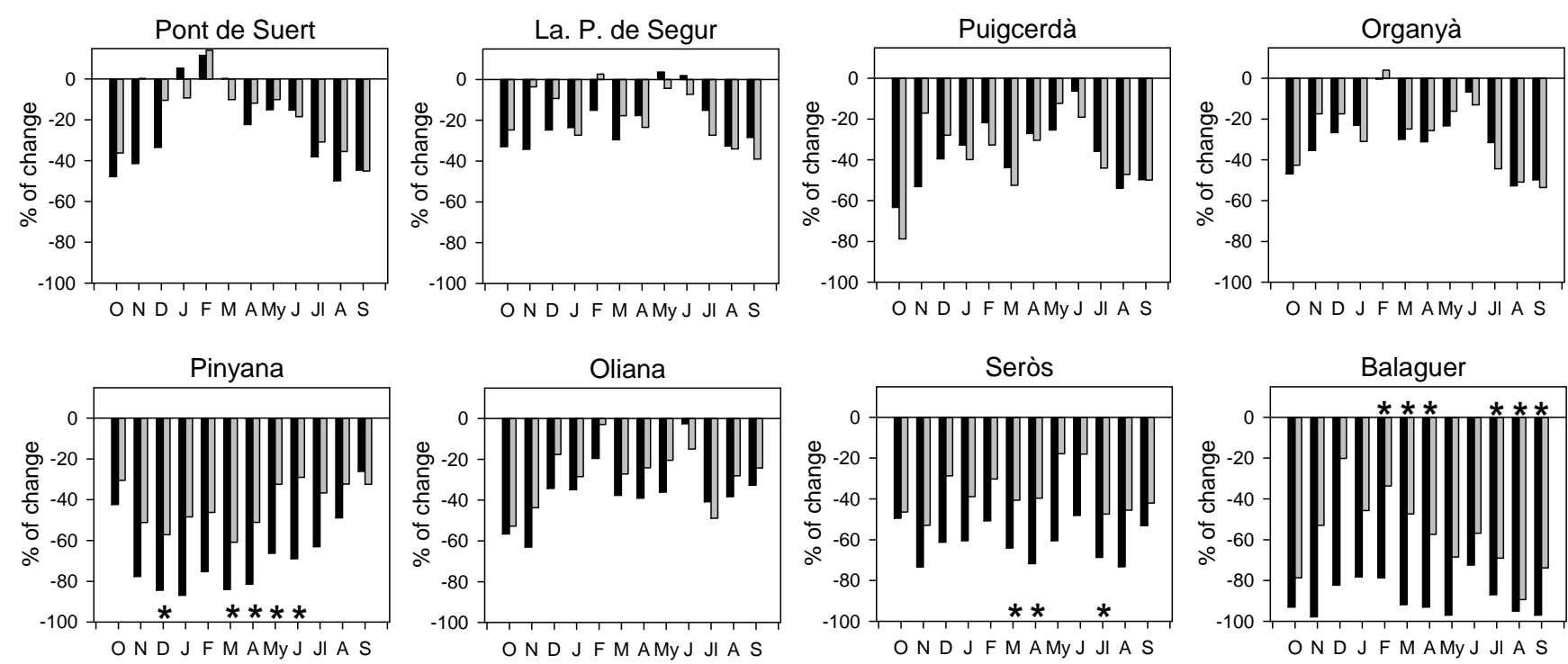

726 Figure 12. Observed percentage change in monthly streamflow from 1951 to 2013, and predicted 727 percentage change according to climatic changes alone. Asterisk indicates a statistically significant 728 difference $(\mathrm{p}<0.05)$ between observed and predicted changes. 


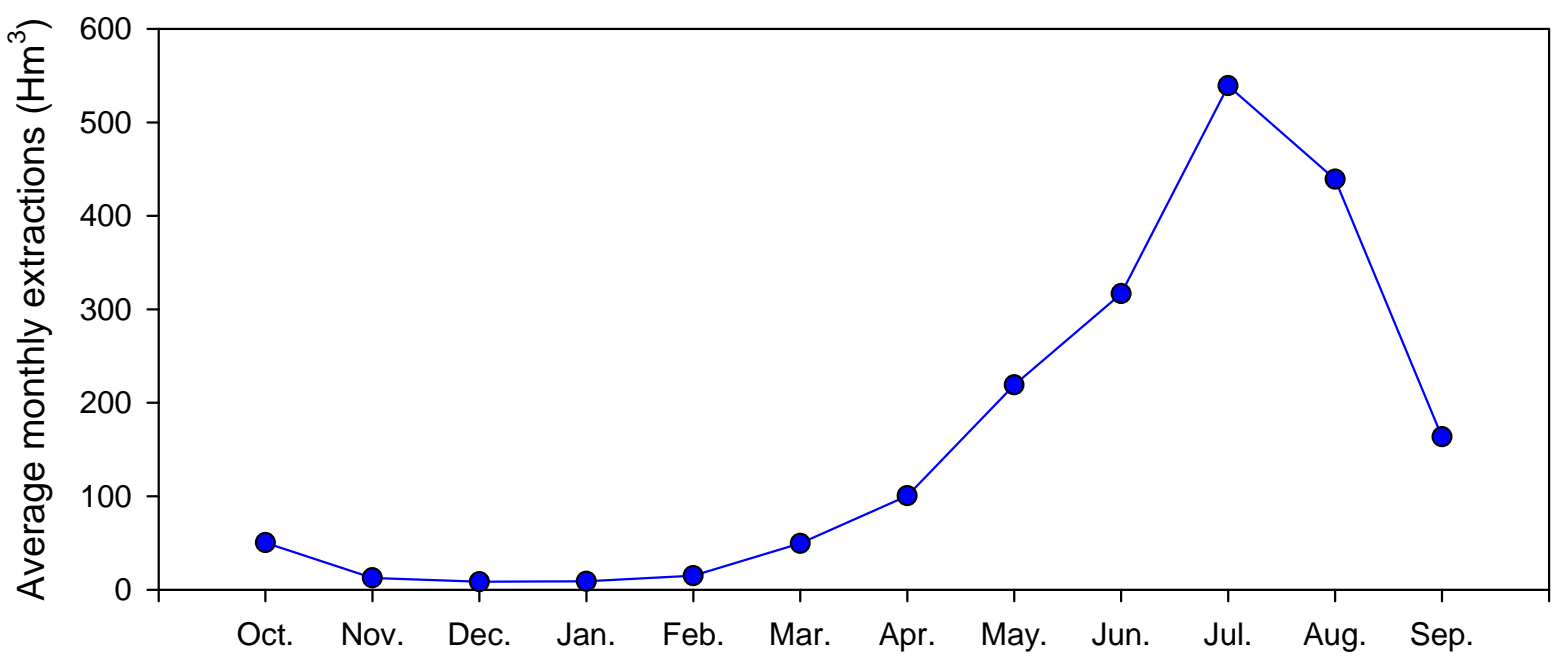

734

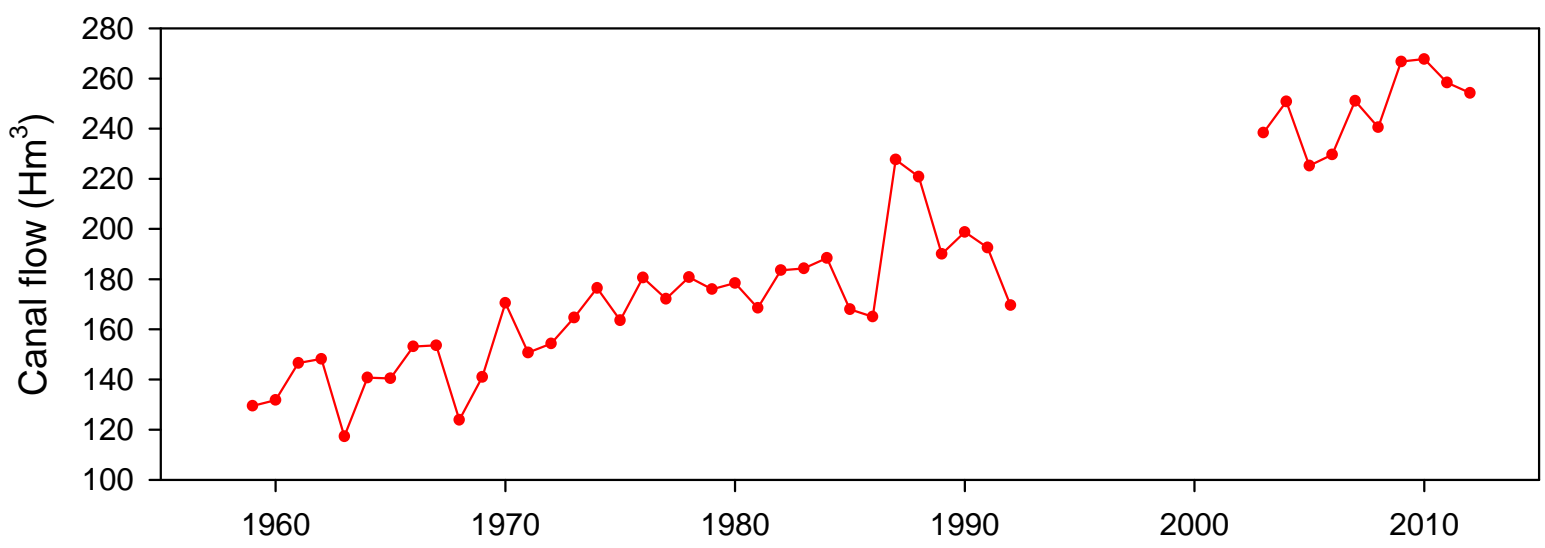

735 Figure 13. Average monthly water extraction for irrigation in the basin (top) and changes in total summer 736 flows in the d'Urgell canal (bottom) from 1958 to 2012. 